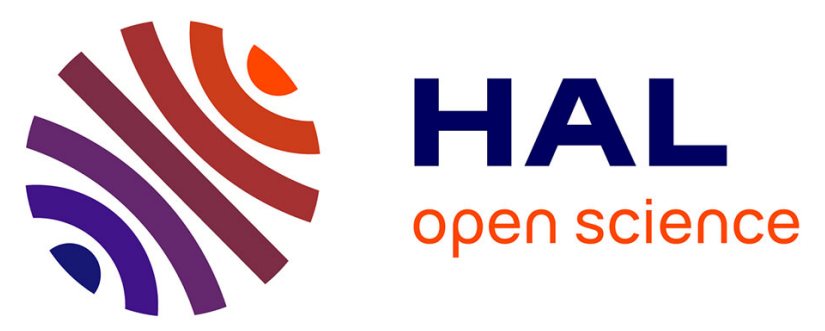

\title{
The effect of pressure and water concentration on the electrical conductivity of dacitic melts: Implication for magnetotelluric imaging in subduction areas
}

\author{
Mickaël Laumonier, Fabrice Gaillard, David Sifré
}

\section{- To cite this version:}

Mickaël Laumonier, Fabrice Gaillard, David Sifré. The effect of pressure and water concentration on the electrical conductivity of dacitic melts: Implication for magnetotelluric imaging in subduction areas. Chemical Geology, 2015, 418, pp.66-76. 10.1016/j.chemgeo.2014.09.019 . insu-01092317

\section{HAL Id: insu-01092317 \\ https://hal-insu.archives-ouvertes.fr/insu-01092317}

Submitted on 5 Jan 2016

HAL is a multi-disciplinary open access archive for the deposit and dissemination of scientific research documents, whether they are published or not. The documents may come from teaching and research institutions in France or abroad, or from public or private research centers.
L'archive ouverte pluridisciplinaire HAL, est destinée au dépôt et à la diffusion de documents scientifiques de niveau recherche, publiés ou non, émanant des établissements d'enseignement et de recherche français ou étrangers, des laboratoires publics ou privés.

\section{(ㅇ)(1) $\$$}

Distributed under a Creative Commons Attribution - NonCommercial - NoDerivatives| 4.0 
The effect of pressure and water concentration on the electrical conductivity of dacitic melts: implication for magnetotelluric imaging in subduction areas

Mickael LAUMONIER ${ }^{1,2,3,4}$, Fabrice GAILLARD ${ }^{1,2,3}$, David SIFRE $^{1,2,3}$

${ }^{1}$ Université d'Orléans, ISTO, UMR 7327, 45071 ORLÉANS, FRANCE

${ }^{2}$ CNRS/INSU, ISTO, UMR 7327, 45071 ORLÉANS, FRANCE

${ }^{3}$ BRGM, ISTO, UMR 7327, BP 36009, 45060 ORLÉANS, FRANCE

${ }^{4}$ Bayerisches Geoinstitut, University of Bayreuth, 95440 BAYREUTH, GERMANY

KEY WORDS: Dacite; electrical conductivity; melt; water; pressure; magnetotelluric interpretation

\section{Abstract}

Silica-rich hydrous magmas are commonly stored in crustal reservoirs, but are also present at mantle depths in subduction contexts as a result of slab melting in presence of considerable amounts of water and other volatile species. Magnetotelluric surveys frequently identify highly conductive zones at crustal or mantle depths possibly revealing the presence of such silica-rich melts and this can be used to trace the cycling of water in subduction zones and its relationship with arc-magmatism. The achievement of such a purpose is impeded by poor knowledge of the electrical conductivity of both dry and hydrous silica-rich melts at pressure. To fill this gap, we performed in situ electrical conductivity measurements on a dacitic melt using a 4-wire set up to $1300^{\circ} \mathrm{C}, 3.0 \mathrm{GPa}$ and $\mathrm{H}_{2} \mathrm{O}$ content up to $12 \mathrm{wt}$.\%. Melt conductivity is strongly correlated with its water content, and we reveal a complex effect of pressure being relatively small at low water contents and major at high water contents: with increasing water 
content, the activation volume ranges between 4 (dry) to $25 \mathrm{~cm}^{3} / \mathrm{mol}\left(\mathrm{H}_{2} \mathrm{O}=12 \mathrm{wt} . \%\right)$ and the activation energy decreases from $96 \mathrm{~kJ}$ (dry) to $62 \mathrm{~kJ}\left(12 \mathrm{wt} \% \mathrm{H}_{2} \mathrm{O}\right)$. By comparison with diffusivity data, sodium appears to be the main charge carrier, even at high (12 wt.\%) water content. A T-P- $\left[\mathrm{H}_{2} \mathrm{O}\right]$ model predicting the conductivity of dacitic melts shows that crustal and mantle wedge conductive bodies can be interpreted by the presence of silica-rich, hydrous, partially crystallized magma.

\section{Introduction}

Outcrops of deep rocks, showing sections of the upper mantle and of the crust, provide an indirect snap shot of deep processes as they have cooled slowly during emplacement, resulting in large modifications of their textures, chemical compositions and mineralogy. In particular, melting processes that can induce large scale mechanical weakening (Holtzmann et al., 2003; 2012; Katz et al., 2006; Holtzmann \& Kohlstedt, 2007; Kohlstedt \& Holtzmann, 2009; Hashim et al. 2013) are mostly erased during the exhumation and cooling of deep rocks. In order to map and understand melting processes occurring at depth, geophysical investigations (e.g. magnetotelluric, seismic tomography) must be deployed over the regions of interest. Magnetotelluric investigations, for example, provide evidence for anomalously high electrical conductivity in the oceanic upper mantle (Evans et al., 2005; Baba et al., 2006; Naif et al., 2013; Key et al., 2013), under the Andean arc (Booker et al., 2004; Unsworth et al., 2013) or in the crust below the South Himalayan ranges (Unsworth et al., 2005). The detection of such highly conductive regions reveals the existence of deep phases having highly mobile charge carriers and being connected over large distance. Experimental investigations have shown that partial melts can trigger high conductivity (Roberts \& Tyburczy, 1999; Gaillard \& Iacono-Marziano, 2005; ten Grotenhuis et al., 2005; Gaillard et al., 2008; Yoshino et al., 2010; Hashim et al., 2013; Sifré et al., 2014). The presence of melt is 
in particular the most likely explanation for the large conductive region beneath the AltiplanoPuna Volcanic Complex (APVC; Booker et al., 2004; Unsworth et al. 2013). Considering the conjunction of (i) the uplift of the crust centred on Uturuncu volcano, (ii) the geothermal springs, and the (iii) dimension of the conductive body, a major replenishment has likely occurred and this demands the thorough appraisal of the storage conditions of melt at depth in the APVC system (de Silva, 1989a, b; Pritchard \& Simons 2002; 2004; de Silva et al., 2006; de Silva \& Gosnold, 2007; Sparks et al., 2008; Del Potro et al., 2013; Muir et al., 2014). The quantitative interpretation of such a structure revealed by magnetotelluric profiles requires robust laboratory characterisation under controlled conditions. So far, several works have addressed the electrical conductivity of silicate melts (Presnall et al., 1972; Waff \& Weill, 1975; Tyburczy \& Waff, 1983; 1985; Robertz \& Tyburczy, 1999; Gaillard, 2004; Bagdassarov et al., 2004; Maumus et al., 2005; Pommier et al., 2008; 2010; Yoshino et al., 2010; Ni et al., 2011; Poe et al. 2008; Hashim et al., 2013; Sifré et al., 2014), but few of them have addressed hydrous melts (Gaillard, 2004; Pommier et al., 2008; Ni et al., 2011; Hashim et al., 2013; Sifré et al., 2014) and the effect of pressure on melt conductivity remains unclear.

This study presents experimental results of in situ electrical conductivity measurements acquired on a dacite from Uturuncu Volcano at various pressure, temperature and water content. A model integrating the effects of pressure, temperature and water concentration is established from the data. Then, we discuss the role of water and pressure on electrical conductivity and the applications to the interpretation magnetotelluric surveys. We discuss the electrical anomalies underneath the Unturuncu volcanic centre, but we also also present quantitative interpretations of the electrical structures below other volcanic areas in arcsettings, where hydrated dacitic melts are likely (Usu, Taupo, Merapi and Saint Helens volcanoes). Finally, we conclude with the possibility of detecting super hydrous melts 
resulting from melting of slab (e.g. Schiano et al., 1995; Neumann \& Wulff-Pedersen, 1997; Shimizu et al., 2004; Ishimaru et al., 2007; Bali et al., 2008), since such melts must trigger high electrical conductivity at ca $90 \mathrm{~km}$, at the base of the mantle wedge.

\section{Background on electrical conductivity}

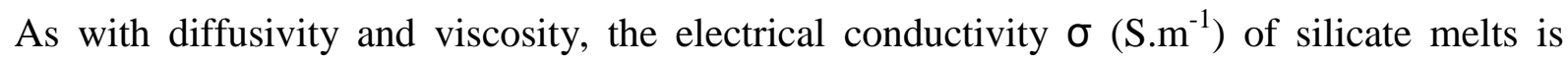
pressure and temperature dependant, and can be described by an Arrhenius law:

$$
\sigma=\sigma_{0} \exp \left(\frac{-E a-P \Delta V}{\mathfrak{R} T}\right)
$$

where $\sigma_{0}$ is the preexponential factor $(\mathrm{S} / \mathrm{m})$, Ea is the activation energy $(\mathrm{J}), \Delta \mathrm{V}\left(\mathrm{cm}^{3} / \mathrm{mol}\right)$ is the activation volume, $\mathrm{T}$ is the temperature $(\mathrm{K}), \mathrm{P}$ is pressure $(\mathrm{Pa})$ and $\Re$ is the universal gas constant. The electrical conductivity is the sum of the individual transport mechanisms; however, the electrical conductivity is generally dominated by one or two mechanisms (Gaillard, 2004). In amorphous (melts and glasses) silicate compositions, the mobility of ionic species dominates. Ionic conductivity is connected to diffusive transport of charge carriers within the melt, and follows the Nernst-Einstein equation:

$$
\sigma_{i}=\frac{D_{i} \cdot q_{i}^{2} \cdot N_{i}}{k \cdot T \cdot H r}
$$

with the tracer diffusion coefficient $D_{i}\left(\mathrm{~m}^{2} \cdot \mathrm{s}^{-1}\right)$ of an ion $i$, its charge $q_{i}(\mathrm{C})$, the concentration of $i\left(\mathrm{~m}^{-3}\right)$, the Boltzmann constant $k\left(1.38 .10^{-23} \mathrm{~J} \cdot \mathrm{K}^{-1}\right)$, the temperature $\mathrm{T}(\mathrm{K})$ and the Haven ratio $\mathrm{Hr}$. The Haven ratio $\mathrm{Hr}$ of silicate melt or glass is related to the mechanisms of migration of the charge carriers within the melt, and generally ranges between 0.2 and 1 (Heinemann \& Frischat, 1993). Gaillard (2004) used $H r=1$ for rhyolitic melts. 


\section{Experimental Methods}

\subsection{Starting materials}

\subsubsection{Sample syntheses}

Electrical measurements were performed on a dacitic rock from Uturuncu volcano, located in the Southwest Bolivia (Altiplano-Puna Volcanic Complex). It has been exhaustively studied under the reference UTU41B (Muir et al., 2014). It consists in phenocrysts of plagioclases embedded in a matrix of orthopyroxene, biotite, ilmenite and Ti-magnetite groundmass. Its bulk chemical composition is given in Table 1 .

The dacite was first crushed in an agate mortar into a powder (grain size $<45 \mu \mathrm{m}$ ). The powder was placed in a platinum crucible and heated to $1000^{\circ} \mathrm{C}$ in air at 1 atmosphere in order to remove volatile species. Then, the crushed dacite was molten at $1450^{\circ} \mathrm{C}$ for 3 hours, resulting in a glass with less than $0.05 \mathrm{wt} . \%$ of water and no detectable amount of $\mathrm{CO}_{2}$. The glass obtained was (1) drilled to provide dry samples for conductivity measurements or (2) crushed for the synthesis of 3 hydrated samples.

Hydrated samples were prepared by adding the desired amount (mass) of water to the glassy powder in a welded shut capsule. Syntheses of hydrated glasses were done in internally heated pressure vessel for 3 days ended by a rapid quench at $300 \mathrm{MPa}, 1200^{\circ} \mathrm{C}$ and $350 \mathrm{MPa}$, $1020^{\circ} \mathrm{C}$ for the glass containing 3.3 and $7.1 \mathrm{wt} . \%$ of water respectively (see also next section). The glass with 12.2 wt. $\% \mathrm{H}_{2} \mathrm{O}$ was synthesized in piston cylinder at $1.5 \mathrm{GPa}, 1000^{\circ} \mathrm{C}$ for 13 hours using a $3 / 4$ inch assembly. Dry and hydrous starting materials are crystal- and bubblefree at the micrometre scale, except the $\left[\mathrm{H}_{2} \mathrm{O}\right]=12.2$ wt.\% sample that contained few amphiboles (less than 5\% in volume) resulting most likely from crystallization during quench. The 3.3 wt. $\% \mathrm{H}_{2} \mathrm{O}$ glass was synthesized in a $15 \mathrm{~mm}$ diameter capsule so as to drill cylindrical samples. The two other syntheses were performed in $5 \mathrm{~mm}$ diameter capsule, and 
samples were prepared after crushing and cold pressed reconstitution of pellets with the desired dimension (see section in situ electrical measurements).

\subsubsection{Determination of the water concentration}

Double polished chips of the four synthetic glasses were analysed by Fourier Transform Infrared spectroscopy (FTIR) to check their water concentration (Microscope IR Continu $\mu$ m coupled with a Nicolet 6700 spectrometer and a MCT detector). An IR source, a KBr beam splitter and $\mathrm{a} \mathrm{CaF}_{2}$ window were used to acquire absorption spectra with 200 scans and a resolution of $4 \mathrm{~cm}-1$ in the range $6000-1500 \mathrm{~cm}^{-1}$. Each sample was analysed through a profile (1.3 to $2.0 \mathrm{~mm}$ in length) of 20 spots minimum to check its homogeneity. A linear baseline correction was used to determine the peak height absorbance, and we calculated the water concentration by the Beer-Lambert law, using extinction coefficients reported by Wysoczanski \& Tani (2006) and density calculated after Ohlhorst et al., (2001). The thickness of the sample was measured by the calibrated stage of the microscope, and checked by a Mitutoyo digital micrometre. The propagated uncertainty takes into account the accuracy of (1) the thickness $( \pm 3 \mu \mathrm{m}),(2)$ the absorbance peak height, (3) glass density and (4) extinction coefficient, resulting in a maximal error in $\left[\mathrm{H}_{2} \mathrm{O}\right]$ content of $10 \%$ relative. To minimize the uncertainty, samples were kept as thick as possible but transparent for IR rays (thickness < $200 \mu \mathrm{m})$. When possible, the fundamental $\mathrm{H}_{2} \mathrm{O}$-stretching vibration was used $\left(3530 \mathrm{~cm}^{-1}\right)$. Otherwise, when the signal of the fundamental stretching $\mathrm{H}_{2} \mathrm{O}$ vibration was oversaturated, the water concentration was determined by adding the molecular water $\left(5200 \mathrm{~cm}^{-1}\right)$ and $\mathrm{OH}-$ $\left(4500 \mathrm{~cm}^{-1}\right)$ stretching vibrations (Fig. 1A to C). The hydrated synthetic glasses contain 3.3 ( \pm 0.3$), 7.1( \pm 0.7)$ and $12.2( \pm 0.5)$ wt.\% of homogeneously dissolved water (Fig. 1D). 


\subsection{In situ electrical measurements}

\subsubsection{Internally Heated Pressure Vessel (IHPV)}

Low-pressure experiments $(\mathrm{P}<300 \mathrm{MPa})$ were conducted in a gas medium IHPV following the same protocol as Gaillard et al. (2004) or Pommier et al. (2008; precision of $1 \mathrm{MPa}$ on the pressure and $2^{\circ} \mathrm{C}$ on the temperature). The $5 \mathrm{~mm}$ diameter sample was intercalated between alumina and surrounded by an Au-Pd capsule welded shut at one end, and closed by $\mathrm{SiO}_{2-}$ $\mathrm{PO}_{3}-\mathrm{H}_{2} \mathrm{O}$ cement at the other end to keep the water in the sample. The resistance of the sample was measured radially, using a $1 \mathrm{~mm}$ Platinum wire in the middle of the sample (internal electrode) and a Pt foil wrapping the sample (external electrode). The whole assembly was located in an isothermal zone checked by 2 thermocouples and controlled by a molybdenum two-winding furnace. The geometry of the sample was stable during the experiment and checked after experiments, resulting in negligible effects on the conductivity measurements. More details about the protocol are provided in Gaillard (2004) and Pommier et al. (2008).

\subsubsection{Piston cylinder}

"High pressure experiments" $(0.5<\mathrm{P}<3.0 \mathrm{GPa})$ were conducted in piston cylinder with an assembly modified after Sifre et al. (2014). Cylindrical samples were obtained by drilling glassy blocks or by cold pressing the glassy powders to form a sample of $5.0 \mathrm{~mm}$ in diameter. These cylinders were inserted in $1 / 2$ and/or $3 / 4$ inches assemblages. The thermocouple is in contact with the internal electrode and gives the temperature of the sample with a precision of $\sim 5^{\circ} \mathrm{C}$ (Fig. 2). The external electrode is the platinum foil wrapping the sample and the upper pieces of the assembly (alumina, MgO-AlSiMag and the nickel plug). The sample is chemically and electrically isolated from the rest of the assembly by 2 disks and a tube of alumina. The rest of the assembly (graphite furnace, Pyrex and talc) is a conventional $3 / 4$ or $1 / 2$ 
inch assembly used for piston cylinder experiments. A $10 \%$ correction on pressure was applied in order to account for frictional force of the $\mathrm{MgO}$, resulting in a precision of $\sim 0.1$ GPa. See also water conservation in supplementary information.

Experiments in piston cylinder used a 4-wire setup to reduce perturbation of the electrical cell, thus allowing a better precision on measurements of conductive samples (Gaillard et al., 2008; Pommier et al., 2010; Sifre et al., 2014; see also sample's resistance acquisition in supplementary information). Sample examination using SEM showed a reduction of the diameter by about 8 to $12 \%$ depending on the starting material (drilled cylinder or cold pressed powder). The length of the sample also slightly reduced and was carefully measured after experiment, ranging from 1.87 to $4.62 \mathrm{~mm}$. Relatively short samples were favoured to lower the temperature gradient.

After impedance measurements during heating and cooling paths, the sample was quenched by shutting down the furnace power while manually maintaining the pressure as close as possible to the target pressure. The cooling of the sample lasted approximately 10 seconds, resulting in a cooling rate too slow to impede the growth of quench crystals in most experiments (Fig. SI2). Typical run duration was short, i.e. of the order of 3 to 5 hours, in order to reduce potential sample dehydration. Only the dry experiment UTU41B-0e lasted 24 hours to test the reproducibility of conductivity measurement through time (see Fig. SI1). Once recovered from the piston cylinder assembly, the samples were placed in epoxy resin to be observed by SEM for textural observation and accurate determination of the geometric factor (Fig. SI2).

\subsection{Impedance spectra, resistance \& determination of the conductivity}

Electrical conductivity was derived from impedance complex spectroscopy (Roberts and Tyburczy, 1994), as a function of the electrical frequency. We used a Solartron 1260 Gain Phase Analyzer (Schlumberger Co.) to obtain impedance spectra (Fig. 3). Impedance spectra 
for the dacitic melts typically range from 1 to $10^{6} \mathrm{~Hz}$ and were visualized in a Nyquist plane (Z',Z'). In this frequency range, the electrical response of the sample can be modelled as different equivalent electrical circuits depending on the resistance range. At relatively low temperatures, corresponding in our case to relatively low resistance ( $\mathrm{R}>\sim 10^{5} \mathrm{ohm}$, Fig. $\left.3 \mathrm{~A}\right)$, the electrical response can be represented by a semicircle followed by a linear segment (Fig. $3 \mathrm{~A})$ in the (Z', Z') complex plan, being equivalent to that of a resistor in series with a resistor and a capacitor in parallel (Stephen \& Dillenburg, 1995). At higher temperature, basically corresponding to a impedance $\sim 10^{1}<\mathrm{R}<\sim 10^{2} \mathrm{ohm}$, the electrical response is equivalent to that of a resistor and inductance mounted in parallel, and is characterized by a nearly vertical curve crossing $Z "=0$ corresponding to the sample resistance (Fig. 3C). Intermediate temperatures, yielding intermediate resistance values, displayed electrical response being intermediate between the 2 previous end-member cases (Fig. 3B).

The resistance of the sample can be read on the $Z^{\prime}$ axis (X-axis) and corresponds to the intersection of the impedance spectra with the Z' axis (Fig. 3). The conductivity of the sample can be calculated from the resistance and a geometric factor $\mathrm{G}$ following the relations:

$$
\sigma=(G \cdot R)^{-1}
$$

where

$$
G=\frac{2 \pi L}{\operatorname{Ln}\left(d_{\text {ext }} / d_{\text {int }}\right)}
$$

The geometric factor $G(m)$ depends on the length $L(m)$, and the external $\left(\mathrm{d}_{\text {ext }}\right)$ and internal $\left(\mathrm{d}_{\text {int }}\right)$ diameters (in $\mathrm{m}$ ) of the sample respectively. The dimensions of the sample are measured on axial, longitudinal section after experiments by Scanning Electron Microscope. The precision of the dimension measurements is better than $10 \mu \mathrm{m}$. The precision on the sample dimension represents the most important source of error on the conductivity; the latter being less than $0.2 \log$ units. Other uncertainties come from the precision of the resistance $R( \pm 5$ ohm, Pommier et al., 2008) and the precision of the temperature $\left(\sim 5^{\circ} \mathrm{C}\right)$. 


\section{Results}

\subsection{Post experimental water content}

The experimental details are summarized in Table 2. Possible water loss and heterogeneity were checked by FTIR analyses. No significant water loss was noticed after the experiments presented in this study (Fig. 4). Basically, the same data dispersion can be observed as in the starting materials (see the error bar in the syntheses in Fig. 4), attesting a homogeneous water distribution.

\subsection{Electrical measurements}

\subsubsection{Effect of $\mathrm{T}$ (Heating-cooling paths)}

Experiments were generally conducted in the $400-1200^{\circ} \mathrm{C}$ temperature range, covering the glass and liquid domains (Table 2). In most cases, at least 2 heating-cooling cycles were operated, in order to appreciate the reproducibility. The conductivity of the "dry" dacite at $\mathrm{P} \approx$ $0.5 \mathrm{GPa}$ is shown in Figure 5 as a function of the reciprocal temperature. During the first heating stage at $\mathrm{T}<840^{\circ} \mathrm{C}$, the electrical conductivity is significantly lower than the conductivity obtained during the subsequent temperature cycles. It approaches to the subsequent paths between 700 and $750^{\circ} \mathrm{C}$ (deviation form the dashed grey line) which basically correspond to the glass transition $\left(\mathrm{Tg}=740^{\circ} \mathrm{C}\right)$ calculated for the dry dacite according to Giordano et al. (2008). We interpret such a difference by an imperfect contact between the sample and the electrodes, resulting in a more resistive signal, until the sample becomes soft enough to perfectly wet the electrodes. The reproducibility of the subsequent cooling-heating-cooling stages is nearly perfect.

As shown in figure 5, electrical conductivity of all compositions increases with the temperature, following an Arrhenius law. The conductivity values of each dry and hydrous composition define a single trend in the large temperature range investigated $(400<\mathrm{T}<$ 
$1250^{\circ} \mathrm{C}$ ) suggesting the same transport mechanisms operating in both glass and liquid domains. Both activation energy $(\mathrm{Ea})$ and preexponential $\left(\sigma_{0}\right)$ factors were however calculated from results obtained in the melt temperature range as defined by Giordano et al. (2008) (Table 2).

\subsubsection{Effect of $\mathrm{H}_{2} \mathrm{O}$ and Pressure}

The figures 5 and 6 shows the obtained electrical conductivities of the dacitic melt for different water contents and pressures. The presence of water significantly increases the electrical conductivity: the dacite with 12 wt. $\%$ of water is $\sim 1.5$ order of magnitude more conductive than the dry one at $3 \mathrm{GPa}$. In contrast, pressure decreases the electrical conductivity, but its effect is less important than that of water in the range of conditions investigated $\left(0.0<\mathrm{H}_{2} \mathrm{O}<12\right.$ wt. $\left.\% ; 0.15<\mathrm{P}<3.0 \mathrm{GPa}\right)$. Both the Activation Energy (Ea) and the pre exponential factor $\left(\sigma_{0}\right)$ are very sensitive to the amount of water dissolved in the melt (Table 2, Fig. 7). Ea decreases by $\sim 30 \%$ at low pressures between dry and water rich dacitic melts, whereas this decrease tends to vanish at the highest pressures investigated $(\mathrm{P}=3 \mathrm{GPa}$; Fig. 7A). In opposite, the difference in $\sigma_{0}$ between the different water content populations is 3 times larger at $\mathrm{P}=3 \mathrm{GPa}\left(>1.5\right.$ order of magnitude) than at low pressure: $\log \sigma_{0}$ ranges from 2.5 to 2.8 and from 2.6 to $\sim 4$ at 0 and 3 GPa respectively (Fig. 7B).

\section{Discussion}

\subsection{Influence of water and pressure on Ea and $\sigma_{0}$}

The activation volume, $\Delta \mathrm{V}$, strongly depends on the water content, which differs from the previous assumptions (Gaillard, 2004; Pommier et al. 2008; Ni et al., 2011). According to Eq. 7, the calculated activation volumes $(\Delta \mathrm{V})$ of the dacite are $3.9,9.6,16.4$ and $24.7 \mathrm{~cm}^{3} \mathrm{~mol}^{-1}$ for the four samples containing $0.0,3.3,7.1$ and 12 wt.\% of water respectively. Such $\Delta \mathrm{V}$ 
values are comparable with the range of $\Delta \mathrm{V}$ obtained for basalts $\left(24 \mathrm{~cm}^{3} \mathrm{~mol}^{-1}\right.$; Pommier et al., 2008), andesites $\left(18 \mathrm{~cm}^{3} \mathrm{~mol}^{-1}\right.$; Tyburczy \& Waff, 1983) or rhyolites $\left(20 \mathrm{~cm}^{3} \mathrm{~mol}^{-1}\right.$; Gaillard, 2004) at similar pressure $(<1 \mathrm{GPa})$. The relatively important value of $\Delta \mathrm{V}$ indicates a strong effect of pressure on the electrical conductivity, and this effect increases as the melt water content increases. According to Gaillard (2004), such a pressure dependence could be due to a relatively high compressibility of Si-rich melt, but the above discussion indicates that mafic liquids can also have large $\Delta \mathrm{V}$ values.

Activation energy (Ea) varies remarkably with the pressure and the water content, considerably more than proposed by Poe et al. (2012) for a pantelleritic (silica-rich) magma. The range of Ea determined in our experiments (62 to $96 \mathrm{~kJ}$ ) is comprised between those for rhyolitic (48 to $73 \mathrm{~kJ}$ ) and andesitic (72 to $113 \mathrm{~kJ}$ ) compositions (Waff \& Weill, 1975; Tyburczy \& Waff, 1983; 1985; Gaillard, 2004). Our data shows that the activation energy (Ea) of the dacite linearly depends on the water concentration in the $\left[\mathrm{H}_{2} \mathrm{O}\right]$ range 0 to $12 \mathrm{wt} . \%$ (see section "electrical model of dacite"). This relationship is different from the one determined on an obsidian being a logarithm function of the water concentration (Gaillard, 2004). It is also different from the one determined on a basalt (Ni et al., 2011; Sifre et al., in press), being related to the exponential concentration of water, in the range 0 to 6 wt. $\% \mathrm{H}_{2} \mathrm{O}$, at $2 \mathrm{GPa}$. Such differences can result from the range of water concentration investigated, being considerably larger in our study, and/or from the effect of the water on the mobility of the charge carrier, which may be a function of the composition of the silicate melt.

\subsection{Charge carrier}

Assuming that the direct relationship between sodium mobility and electrical conductivity established by Gaillard (2004) is valid for the dacite, Na diffusivity was calculated from the Nernst-Einstein equation (Eq.2), and is plotted versus 1/T in Figure 8. A value of 0.8 was taken for the Haven ratio, in order to follow the trend defined by previous works (rhyolite: $\mathrm{Hr}$ 
$\approx 1$, Gaillard, 2004; basalt: $H r \approx 0.4$, Gaillard \& IaconoMarziano, 2005). The Na diffusivity calculated for the dry dacite lies between the diffusivities of the dacitic and rhyolitic compositions both determined by Henderson et al. (1985) and is about one order of magnitude higher than the values determined on mafic and intermediate compositions (Lowry et al., 1982). We also tested that protons could be the main charge carriers: the diffusivity of proton $\mathrm{H}^{+}$was also calculated using the Nernst-Einstein equation from the conductivity and water contents of hydrated melts (Eq. 2). The calculated proton diffusivity would be only $\sim 0.5 \log$ unit lower than the $\mathrm{Na}$ diffusivity in the same conditions and about 2 orders of magnitude higher than $\mathrm{H}_{2} \mathrm{O}_{\mathrm{m}}$ diffusivity in dacitic melts (Fig. 8, Ni et al., 2009). However, water diffusion studies show that the neutral $\mathrm{H}_{2} \mathrm{O}$ or $\mathrm{H}_{2}$ molecule dominates hydrogen transport in polymerized melts (Zhang et al, 1991; Gaillard et al. 2003; Berhens et al., 2004; Ni et al., 2009). Nowak \& Behrens (1997) found that self-diffusion of protons (i.e. H/D exchanges) is limited by the diffusion of molecular water in haplogranitic melts, water diffusion being, in the case of rhyolitic melts several orders of magnitude lower than $\mathrm{Na}$ diffusion (Fig. 8). Therefore, assuming that water diffusions in dacite and rhyolite are similar, proton diffusion must be slower than molecular $\mathrm{H} 2 \mathrm{O}$ diffusion and consequently, much slower than $\mathrm{Na}^{+}$.We therefore conclude that proton is unlikely to participate in the charge carrier processes in dacitic melts. Iron cannot act as a significant charge carrier as it is an electrical conductor only in iron-rich melts (Barczyinski \& Murawski, 2002; Poe et al. 2012). All in all, it is most likely that sodium is the dominant charge carrier in the dacite, including at high water content (i.e. 12 wt. $\% \mathrm{H}_{2} \mathrm{O}$ ). Water may indirectly participate in charge transport by decreasing the melt viscosity, then enhancing Na mobility (Fig. 8; see also Fig. SI3; Gaillard, 2004). The different water contents investigated in this study must show the effect of water on both $\mathrm{Na}$ diffusion and electrical conductivity (Fig. $6 \& 8$ ). Our findings concerning sodium as main charge carrier agrees with previous works, suggesting that electrical conduction in silicate melts is 
dominated by light alkalis such as Li and Na (Pfeiffer, 1998; Gaillard, 2004, Gaillard \& Iacono-Marziano, 2005; Pommier et al, 2008).

\subsection{Electrical T-P- $\mathrm{H}_{2} \mathrm{O}$ model of dacite}

A single model taking into account the effect of temperature, pressure and water concentration was established from all data following the general Arrhenius law in Eq. (1):

$$
\begin{gathered}
\sigma 0=\exp (a w+b+P *(c w \\
+d)) \\
, \\
E a=(e w+f) \text { and } \\
V=(g w+h)
\end{gathered}
$$

where $w$ is the water concentration (wt. \%) and a to $\mathrm{h}$ are constant values adjusted on the conductivity data of the dacite and defined in Table 3.

Calculated conductivities using Eq. (5-6-7) are plotted in an Arrhenius diagram together with the measured data in (Fig. 6). The correlation coefficient associated to the hydrous dacite model is 0.996 , and the average difference between the fit and the measured values is equal to 0.028 .

Given the absence of studies on electrical conductivity of dacite (dry and hydrous), we now compare our model with previous experimental works on felsic magmas (a rhyolite from Gaillard, 2004 and a metapelite from Hashim et al., 2013) and the Sigmelts model which simulates a dacite by taking into account the $\mathrm{Na}_{2} \mathrm{O}, \mathrm{SiO}_{2}$ and water contents (Pommier \& $\mathrm{Le}$ Trong, 2011). The electrical conductivity of the dacite is plotted against the water content at 850 and $1000^{\circ} \mathrm{C}$ (Fig. 9). Generally, the effect of water is more important than previously 
proposed (Gaillard, 2004; Pommier et al., 2008; Pommier \& Le Trong, 2011). For instance, contrary to our model, the Sigmelts predicts a somehow complicated dependence on water contents, which incidentally, only differs by $\sim 0.5-1 \log$ unit in the water concentration range 0 -10 wt. $\%$ at $850-1000^{\circ} \mathrm{C}$ and $0.5 \mathrm{GPa}$ (Fig. 9A \& B). The difference is much more important ( 1.5 order of magnitude) at 12 wt.\% $\mathrm{H}_{2} \mathrm{O}$ and $2 \mathrm{GPa}$ (Fig. 9A \& B). In opposite, the influence of pressure is less important than proposed by previous studies for water contents ranging from 0 to 10 wt.\% (Tyburczy \& Waff, 1983; Gaillard, 2004; Pommier et al., 2008), but none of the existing studies describe the strong dependence of the effect of pressure on water content, which is highlighted here.

The comparison of electrical conductivity of the dacite with silica-rich melts highlights its specific electrical behavior (Fig. 9; Gaillard, 2004; Hashim et al., 2013). At low water contents $(<\sim 4.5 \mathrm{wt} . \%)$, the electrical conductivity of the rhyolite is higher than the dacite one (Fig. 9). Such a difference can be linked to the larger amount of $\mathrm{Na}$ in the rhyolite; the latter has $\mathrm{Na}_{2} \mathrm{O}$ content of 4.15 , that is, twice that of the dacite or may be related to the fact that alkalis are more mobile in polymerized melts (Pfeiffer, 1998; Mungall, XXX see citation in gaillard, 2004; Gaillard and IaconoMarziano, 2005). The electrical conductivity increase of the rhyolitic melt is lessened beyond $\sim 1$ wt. \% of water, whereas the linear dependence of Log $\sigma$ of the dacite with water indicates a constant increase of the conductivity in a large range of water content (at least up to 12 wt.\%; Fig. 9).

The leucogranitic melt obtained during partial melting experiments performed by Hashim et al. (2013) can be compared to our model. The melt $\left(\mathrm{SiO}_{2} \approx 74.8\right.$ wt.\%; $\mathrm{Na}_{2} \mathrm{O} \approx 2.65$ wt.\%) was produced from a metapelite up to $24 \%$ in volume, therefore truly connected, giving a melt conductivity Log $\sigma$ ranging between -0.43 and +0.01 (Hashim et al., 2013). In the same P-T- $\left[\mathrm{H}_{2} \mathrm{O}\right]$ conditions $\left(0.30 \mathrm{GPa}, 850^{\circ} \mathrm{C}\right.$ and 6 wt. $\% \mathrm{H}_{2} \mathrm{O}$ in the melt $)$, the dacite has a 
conductivity $\log \sigma=-0,04$ (Fig. 9A). Therefore, in those conditions, our model predicts an electrical conductivity very close to that estimated by Hashim et al. (2013).

\subsection{Implications for magnetotelluric survey}

\subsubsection{Detection of magmatic reservoir in the crust}

Several MT surveys have identified high conductive bodies at crustal depths and some of them are interpreted or could be interpreted as magma reservoir containing a significant melt fraction (e.g. Schwarz \& Kruger, 1997; Echternacht et al., 1997; Matsushima et al., 2001; Hoffmann-Rothe et al., 2001; Booker et al., 2004; Hill et al., 2009; Heise et al., 2010; Bertrand et al., 2012; Unsworth et al., 2013; McGary et al., 2014). The cases of the AltiplanoPuna Magma Body (APMB), Mt St Helens, Usu, Taupo and Merapi potential reservoir are discussed here after. To consider the presence of crystals on the bulk eletrial conductivity, we used the modified Archie's law with an m exponent of 1.05 as calibrated after Gaillard \& Iacono Marziano (2005).

\section{$\underline{\mathrm{APMB}}$}

One of the most spectacular electrical anomalies in the crust is the Altiplano-Puna Magma Body (APMB, Chile-Bolivia), a massive body of $80 \mathrm{~km}$ long by $10 \mathrm{~km}$ thick located at 35 $\mathrm{km}$ depth, with a resistivity lower than 1 ohm.m resulting from the presence of melt (Schilling et al., 2006; Unsworth et al., 2013). At shallower depths (1 to $5 \mathrm{~km}$ ), several other conductive bodies are evidenced with a slightly higher resistivity ( 5 ohm.m; Unsworth et al., 2013). Uturuncu Volcano (south Bolivia) has been essentially erupting dacite, and is fed by magma from the APBM (Sparks et al., 2008; Del Potro et al. 2013; Muir et al. 2014). Recent phase equilibrium constrain the storage conditions of the previously erupted dacite at Uturuncu Volcano: the dacite was stored at a depth of $\sim 2$ to $4 \mathrm{~km}, 870^{\circ} \mathrm{C}$, near water-saturated 
conditions $\left(\left[\mathrm{H}_{2} \mathrm{O}\right]=3.2\right.$ wt.\%; Muir et al. 2014). In such conditions, our model shows that the dacite would have a conductivity of $\log \sigma=-0.6(\sigma$ in $\mathrm{S} / \mathrm{m})$, which coincides very well with the resistivity values obtained by geophysicists for shallow bodies (Fig. 10A; Unsworth et al., 2013). Therefore, a magmatic reservoir containing a similar dacite as previously erupted is likely to exist, and its conductivity indicates a low crystal fraction (ca. <30 vol.\%). It has been suggested that such a reservoir can have survived since the precedent eruption (271ka, Sparks et al. 2008), or has been rebuild due to incoming magma from the main body (APMB, Del Potro et al. 2013). The low crystal content, as deduced from the conductivity value, seems difficult to reconcile with secular cooling of remnant magma, unless crystal settling has efficiently operated.

Considering now a dacitic reservoir located at lower crust levels $\left(\mathrm{T}=870^{\circ} \mathrm{C} ; \mathrm{P}=1 \mathrm{GPa}\right.$; $\left[\mathrm{H}_{2} \mathrm{O}\right]=12 \mathrm{wt} \%$ as experimentally constrained for Mt. Pinatubo, Prouteau \& Scaillet, 2003), the associated conductivity would be $\log \sigma \approx 1.1$, much higher than the one of the large body lying at $\sim 35 \mathrm{~km}$ beneath Uturuncu Volcano (Fig. 10A). To explain such conductivity by the presence of dacite, the melt must be water under-saturated (7 to 9 wt.\%, Fig. 10A), or must contain a large amount of solid materials. A more plausible hypothesis is the presence of a more mafic (= more resistive) melt, such as basalt to andesite, commonly found as enclaves in the erupted dacite, and previously proposed as the main magma reservoir (Sparks et al., 2008; Muir et al., 2014). But in absence of experimental data on the electrical conductivity of hydrated andesite, we cannot test this scenario.

\section{$\underline{\text { Usu }}$}

Usu volcano is one of the most active volcano in Japan, with a $\mathrm{SiO}_{2}$ content decreasing from 74 to 69 wt. \% in the last 8 eruptions since 1663 , with a low (< $14 \%$ in volume) phenocryst content (Tomiya \& Takahashi, 2005). Chemical pattern of emitted products suggest that a 
magma chamber still exists (Tomiya \& Takahashi, 2005). A conductive body $(-0.12<\log \sigma$ $<-0.32$ ) reported by Matushima et al. (2001) is located at $\sim 7 \mathrm{~km}$ below the surface. The conductivity of a water-saturated dacitic melt at such depth and 850 to $900^{\circ} \mathrm{C}$ (petrological estimations from Tomiya \& Takahashi, 2005) would match the values obtained by magnetotelluric investigation if it is partially crystallized (crystal fraction $0.45-0.75$; Fig. 10B; Matsushima et al., 2001).

$\underline{\text { Taupo }}$

Conductive bodies were located at $\sim 1 \mathrm{~km}(\log \sigma=-0.3)$ and between 10 and $20 \mathrm{~km}$ depth (Log $\sigma$ up to 0) beneath Taupo Volcano (New Zealand; Heise et al., 2010; Bertrand et al., 2012). The volcano is well characterized for erupting felsic (dacite to rhyolitic) lava (e.g. Sutton et al., 2000). Our model shows that water saturated dacitic magma cannot explain the high conductivities observed (Fig. 10C). Therefore, magma with higher $\mathrm{Na}_{2} \mathrm{O}$ content (rhyolite), or fluids are likely to be present at superficial levels. As for Usu volcano, if the presence of melt is responsible of the conductive signal at mid crustal levels, then a dacitic magma needs to be partially crystallized, or water-under saturated (Fig. 10C). A reservoir composed of a more mafic melt might also be able to reproduce the measured conductivities between 10 and $20 \mathrm{~km}$ depth.

\section{$\underline{\text { Merapi }}$}

In October 2010, Merapi volcano erupted andesitic magma during its largest explosive events in a century. Before this major eruption, a relatively high conductive body was located by MT survey, at 5 to $7 \mathrm{~km}$ depth with a resistivity of $\sim 2 \mathrm{ohm}$.m (Hoffmann-Rothe et al., 2001). The 2010 eruption has been interpreted to follow a rapid ascent, and a short stay in the reservoir (Hoffmann-Rothe et al., 2001; Jousset et al., 2012). Andesite contains $30 \%$ in volume of 
phenocrysts embedded in a dacitic matrix ( $\mathrm{SiO} 2=66-68$ wt. \%, Jousset et al., 2012), therefore comparable to the dacite used in our experiments. The resistivity of $2 \mathrm{ohm} . \mathrm{m}$ at $5-7 \mathrm{~km}$ depth (P $200 \mathrm{MPa})$ corresponds to the one of a dacitic melt close to water saturation $(\sim 5,5 \mathrm{wt} . \%)$ at $840^{\circ} \mathrm{C}$, which is consistent with experimental determination of Merapi's andesite storage conditions (Fig. 10D; Hammer et al., 2000; Borisova et al., 2013; Costa et al., 2013).

\section{$\underline{\text { St Helens reservoir }}$}

Beneath Mt St Helens Volcano (Washington state), a Log $\sigma=0.1$ conductive body lies at $\sim 6$ km depth (Hill et al., 2009). The main eruptive products at Mt St Helens are dacitic in composition (e.g. Rutherford et al., 1985; Smith \& Leeman, 1987; Pallister et al., 2008). However, the model cannot explain such high conductive value by the presence of a water saturated dacite stored at $930^{\circ} \mathrm{C}, 200 \mathrm{MPa}$ (Rutherford et al., 1985), even in favorable conditions (relatively high temperature of $1000^{\circ} \mathrm{C}$, Fig. 10E). Therefore, either the highly conductive body seen by Hill et al (2009) is not a magma (brines or any fluids, see Hashim et al., 2013) or the magma presently stored is not similar to the dacite that produced the previous historical eruption (e.g. Rutherford et al., 1985). The high conductivity, associated to zonation pattern in crystal and the presence of mafic inclusions, suggests the dacite was formed by magma mixing between a mafic deep magma intruding a rhyolitic-like magma being possibly responsible for the low resistive value obtained by geophysical investigation (Clynne et al., 2008; Claiborne et al., 2010).

\subsubsection{Characterisation of mantle silica-rich melts}

\section{$\underline{\text { Natural occurrences constrain on mantle silica-rich melts }}$}

Highly silicic glasses (up to $\mathrm{SiO}_{2}=72$ wt. \%) have often been reported as inclusions, quartz bearing veins and as interstitial glass pockets in upper mantle peridotite, including in 
xenoliths from subduction context (e.g. Schiano et al., 1995; Baker et al., 1995; WulffPedersen et al., 1996; Neumann \& Wulff-Pedersen, 1997; Shimizu et al., 2004; Ishimaru et al., 2007; Bali et al., 2008). Several origins have been proposed for the existence of such felsic melts in the upper mantle like partial melting of peridotite (e.g. Baker et al., 1995; Hirschmann et al., 1998) or reactions between infiltrating basaltic melts and peridotite (WulffPedersen et al., 1996), but in most cases, the presence of hydrous fluids is called to favour low degree of partial melting at the base of the mantle wedge. Hydrous fluids is related to the dehydration (+/- melting) of hydrous phases from the subducting slab (Amundsen, 1987; Baker et al., 1995; Schiano et al., 1995; Chazot et al., 1996; Wulff-Pedersen et al., 1996; Hirschmann et al., 1998; Hermann \& Green, 2001; Scaillet \& Prouteau, 2001; Klemme et al., 2002; Ishimaru et al., 2007; Bali et al., 2008). Klemme et al. (2002) show that the low degree partial melting of eclogite produces melts with 70 wt.\% of $\mathrm{SiO}_{2}$, and up to 5 wt.\% of $\mathrm{Na}_{2} \mathrm{O}$. Therefore, our model can also be applied to the response of a dacitic melt at mantle conditions, corrected to respect the expected low melt fractions.

The P-T conditions for slab melting are $800^{\circ} \mathrm{C}, 2$ to $3 \mathrm{GPa}$ as constrained from thermal modeling (e.g. Peacock et al., 1994). Higher temperatures (900 to $\left.1000^{\circ} \mathrm{C}\right)$ were determined from experiments involving olivine and a trondhjemitic melt (issued from basalt melting) that produced dacitic melts with $\mathrm{SiO}_{2}$ and $\mathrm{Na}_{2} \mathrm{O}$ contents of 64-68 and 5-6 wt.\% respectively in the presence of water (Sen \& Dunn, 1994; Rapp et al., 1999). To produce dacitic melts, water must be in excess, probably up to 15 wt.\% (Stern \& Wyllie, 1981; Prouteau et al., 1999; 2001).

\section{Electrical signature of silica-rich melt-bearing mantle}

To calculate the bulk electrical conductivity of a dacite-bearing peridotite, we consider an olivine aggregate, with electrical properties taken from Roberts \& Tyburczy (1991) and dacitic melt distributed along tubes as observed in Garapic et al. (2013) experiments with low 
melt fraction (1.6 and 3.6 vol.\%). We used the "Tubes model" to calculated the conductivity of the bulk magma with low melt fraction (Grant \& West, 1965; Schmeling, 1985), though almost similar results can be obtain using a film distribution of the melt (Sifre et al., 2014 and reference therein) or the modified Archie's law previously used in this study with a melt connectivity $\mathrm{m}=1.3$ (Glover et al., 2000; Gaillard \& Iacono-Marziano, 2005). The model was built using the equation (5-6-7). In figure 11, we show the electrical conductivity of the cold mantle wedge just above the slab that is percolated by a small fraction (0.01 to 0.10$)$ of dacite with $\left[\mathrm{H}_{2} \mathrm{O}\right]<15$ wt.\%, $\mathrm{T}=800^{\circ} \mathrm{C}$ and $\mathrm{P}=2.5 \mathrm{GPa}$. In such conditions, the electrical conductivity $\log \sigma$ of the mantle ranges from -2.5 to -1.75 and from -2.5 to -0.8 for a melt fraction of 0.01 and 0.10 respectively (Fig. 11). Most of the electrical conductivities reported at depth comprised between 60 and $100 \mathrm{~km}$ in subduction contexts (Booker et al., 2004; Soyer \& Unsworth, 2006; Jodick et al., 2006; Patro \& Egbert, 2008; Brasse et al., 2009; Worzewski et al., 2011; Matsuno et al., 2010) can be explained by a rock containing less than 0.05 melt fraction of water-rich (10 to $15 \mathrm{wt} . \%$ ) dacite. These water concentrations of the melt phase are reasonable according to water solubility at such pressure (e.g. Stern \& Wyllie, 1981; Mysen \& Acton, 1999; Mysen \& Cody, 2004; Prouteau et al., 1999; 2001).

Finally, the conductivity ( $\log \sigma=-0.2)$ determined at 100 to $200 \mathrm{~km}$ depth beneath AltiplanoPuna Volcanic Complex (Bolivia) is almost one order of magnitude higher than the trend defined by the previous studies (Booker et al., 2004; Fig. 11). Such a high value of EC requires a melt fraction larger than 0.20 , or the presence of another volatile such as $\mathrm{CO}_{2}$ (Gaillard et al., 2008; Sifré et al., 2014) more conductive than water and which is particularly rich in erupted products at Uturuncu (Sparks et al., 2008; Muir et al., 2014). 


\section{Conclusions}

Electrical conductivity of a dacite was in situ measured over wide ranges of temperature (400$\left.1300^{\circ} \mathrm{C}\right)$, pressure $(0,15$ to $3.0 \mathrm{GPa})$ and $\mathrm{H}_{2} \mathrm{O}$ content $(0$ to $12 \mathrm{wt} . \%)$. Water has a strong positive influence on the electrical conductivity of the dacite. Pressure decreases the conductivity, and its effect is increasing as melt water content increases. Sodium appears to be the main charge carrier in the $\left[\mathrm{H}_{2} \mathrm{O}\right]$ range investigated. A model was established from the data, allowing the determination of the conductivity in the crust and upper mantle conditions for various $\mathrm{T}-\mathrm{P}-\mathrm{H}_{2} \mathrm{O}$ conditions. We conclude that several electrical anomalies in the crust and the mantle affected by subduction processes can be successfully interpreted as magmatic liquid occurrence and provide constrains on both water and crystal contents. The combination of laboratory measurements and magnetotelluric investigations appears therefore as a promising approach to decipher magmatic system with immediate outcome on the mitigation of volcanic risk.

\section{Acknowledgements}

This work was supported by European Research Council (ERC grant number 279790 attributed to F. Gaillard) and by the Agence Nationale de la Recherche (ANR-10-BLAN62101). We thank D. Muir \& J. Blundy for providing samples from Uturuncu volcano, M. Unsworth for fruitful discussion about MT profile beneath Andean arc, I. Di Carlo for analytical assistance and Y. Morizet. We also thank 2 reviewers and the associate editor for their comments.

\section{References}

Amundsen, H. E. (1987). Evidence for liquid immiscibility in the upper mantle.Nature, 327(6124), $692-695$. 
Baba, K., Chave, A. D., Evans, R. L., Hirth, G., \& Mackie, R. L. (2006). Mantle dynamics beneath the East Pacific Rise at 17 S: Insights from the Mantle Electromagnetic and Tomography (MELT) experiment. Journal of Geophysical Research: Solid Earth (1978-2012), 111(B2).

Bagdassarov, N. S., Maumus, J., Poe, B., \&Bulatov, V. K. (2004). Pressure dependence of T g in silicate glasses from electrical impedance measurements. Physics and Chemistry of Glasses-European Journal of Glass Science and Technology Part B, 45(3), 197-214.

Baker, M. B., Hirschmann, M. M., Ghiorso, M. S., \& Stolper, E. M. (1995). Compositions of near-solidus peridotite melts from experiments and thermodynamic calculation. Nature, 375(6529), 308-311.

Bali, E., Zajacz, Z., Kovács, I., Szabó, C. S., Halter, W., Vaselli, O., Torok, K., Bodnar, R. J. (2008). A quartzbearing orthopyroxene-rich websterite xenolith from the Pannonian Basin, Western Hungary: evidence for release of quartz-saturated melts from a subducted slab. Journal of Petrology, 49(3), 421-439.

Barczynski, R. J., \&Murawski, L. (2002). Mixed electronic-ionic conductivity in transition metal oxide glasses containing alkaline ions. Journal of non-crystalline solids, 307, 1055-1059.

Behrens, H., Zhang, Y., \& Xu, Z. (2004). H< sub $>2</$ sub $>$ O diffusion in dacitic and andesitic melts.Geochimicaetcosmochimicaacta, 68(24), 5139-5150.

Bertrand, E. A., Caldwell, T. G., Hill, G. J., Wallin, E. L., Bennie, S. L., Cozens, N., ... \&Wameyo, P. (2012). Magnetotelluric imaging of upper-crustal convection plumes beneath the Taupo Volcanic Zone, New Zealand.Geophysical Research Letters, 39(2).

Booker, J. R., Favetto, A., \&Pomposiello, M. C. (2004). Low electrical resistivity associated with plunging of the Nazca flat slab beneath Argentina. Nature, 429(6990), 399-403.

Borisova, A. Y., Martel, C., Gouy, S., Pratomo, I., Sumarti, S., Toutain, J. P., ... \& Métaxian, J. P. (2013). Highly explosive 2010 Merapi eruption: evidence for shallow-level crustal assimilation and hybrid fluid. Journal of Volcanology and Geothermal Research, 261, 193-208.

Brasse, H., Kapinos, G., Mütschard, L., Alvarado, G. E., Worzewski, T., \&Jegen, M. (2009).Deep electrical resistivity structure of northwestern Costa Rica.Geophysical Research Letters, 36(2).

Chazot, G., Menzies, M. A., \& Harte, B. (1996). Determination of partition coefficients between apatite, clinopyroxene, amphibole, and melt in natural spinel lherzolites from Yemen: implications for wet melting of the lithospheric mantle. Geochimica et Cosmochimica Acta, 60(3), 423-437.

Claiborne, L. L., Miller, C. F., Flanagan, D. M., Clynne, M. A., \& Wooden, J. L. (2010). Zircon reveals protracted magma storage and recycling beneath Mount St. Helens. Geology, 38(11), 1011-1014. 
Clynne, M. A., Calvert, A. T., Wolfe, E. W., Evarts, R. C., Fleck, R. J., \&Lanphere, M. A. (2008). The Pleistocene eruptive history of Mount St. Helens, Washington, from 300,000 to 12,800 years before present.US Geological Survey professional paper, (1750), 593-627.

Costa, F., Andreastuti, S., Bouvet de Maisonneuve, C., \& Pallister, J. S. (2013). Petrological insights into the storage conditions, and magmatic processes that yielded the centennial 2010 Merapi explosive eruption. Journal of Volcanology and Geothermal Research, 261, 209-235.

Del Potro, R., Díez, M., Blundy, J., Camacho, A. G., \&Gottsmann, J. (2013).Diapiric ascent of silicic magma beneath the Bolivian Altiplano.Geophysical Research Letters, 40(10), 2044-2048.

De Silva, S. L. (1989). Altiplano-Puna volcanic complex of the central Andes.Geology, 17(12), 1102-1106.

De Silva, S. L. (1989). Geochronology and stratigraphy of the ignimbrites from the $2130^{\prime}$ S to $2330^{\prime} \mathrm{S}$ portion of the central Andes of northern Chile.Journal of Volcanology and Geothermal Research, 37(2), 93-131. de Silva, S., Zandt, G., Trumbull, R., \&Viramonte, J. (2006). Large-scale silicic volcanism-The result of thermal maturation of the crust.Advances in Geosciences, Volume 1: Solid Earth (SE), 1, 215.

de Silva, S. L., \&Gosnold, W. D. (2007). Episodic construction of batholiths: Insights from the spatiotemporal development of an ignimbrite flare-up. Journal of Volcanology and Geothermal Research, 167(1), 320-335.

Echternacht, F., Tauber, S., Eisel, M., Brasse, H., Schwarz, G., \&Haak, V. (1997).Electromagnetic study of the active continental margin in northern Chile.Physics of the earth and planetary interiors, 102(1), 69-87.

Evans, R. L., Hirth, G., Baba, K., Forsyth, D., Chave, A., \& Mackie, R. (2005). Geophysical evidence from the MELT area for compositional controls on oceanic plates.Nature, 437(7056), 249-252.

Gaillard, F., Schmidt, B., Mackwell, S., \&McCammon, C. (2003). Rate of hydrogen-iron redox exchange in silicate melts and glasses. GeochimicaetCosmochimicaActa, 67(13), 2427-2441.

Gaillard, F. (2004). Laboratory measurements of electrical conductivity of hydrous and dry silicic melts under pressure. Earth and Planetary Science Letters, 218(1), 215-228.

Gaillard, F., Malki, M., Iacono-Marziano, G., Pichavant, M., \&Scaillet, B. (2008).Carbonatite melts and electrical conductivity in the asthenosphere.Science, 322(5906), 1363-1365.

Gaillard, F., \& Iacono-Marziano, G. (2005). Electrical conductivity of magma in the course of crystallization controlled by their residual liquid composition.Journal of Geophysical Research: Solid Earth (1978-2012), 110(B6). 
Garapić, G., Faul, U. H., \& Brisson, E. (2013). High-resolution imaging of the melt distribution in partially molten upper mantle rocks: evidence for wetted two-grain boundaries. Geochemistry, Geophysics, Geosystems, 14(3), 556-566.

Giordano, D., Russell, J. K., \&Dingwell, D. B. (2008). Viscosity of magmatic liquids: a model. Earth and Planetary Science Letters, 271(1), 123-134.

Glover, P. W., Hole, M. J., \& Pous, J. (2000). A modified Archie's law for two conducting phases. Earth and Planetary Science Letters, 180(3), 369-383.

Grant, F. S., \& West, G. F. (1965). Interpretation theory in applied geophysics (Vol. 130). New York: McGrawHill.

Green, T. H., \& Ringwood, A. E. (1968). Genesis of the calc-alkaline igneous rock suite.Contributions to Mineralogy and Petrology, 18(2), 105-162.

Hammer, J. E., Cashman, K. V., \& Voight, B. (2000). Magmatic processes revealed by textural and compositional trends in Merapi dome lavas. Journal of Volcanology and Geothermal Research, 100(1), 165192.

Hashim, L., Gaillard, F., Champallier, R., Le Breton, N., Arbaret, L., \&Scaillet, B. (2013). Experimental assessment of the relationships between electrical resistivity, crustal melting and strain localization beneath the Himalayan-Tibetan Belt.Earth and Planetary Science Letters, 373, 20-30.

Heinemann, I., \&Frischat, G. H. (1993). The sodium transport mechanism in Na2O. 2SiO2 glass determined by the Chemla experiment.Physics and chemistry of glasses, 34(6), 255-260.

Heise, W., Caldwell, T. G., Bibby, H. M., \& Bennie, S. L. (2010). Three-dimensional electrical resistivity image of magma beneath an active continental rift, Taupo Volcanic Zone, New Zealand.Geophysical Research Letters, 37(10).

Henderson, P., Nolan, J., Cunningham, G. C., \& Lowry, R. K. (1985).Structural controls and mechanisms of diffusion in natural silicate melts.Contributions to Mineralogy and Petrology, 89(2-3), 263-272.

Hermann, J., \& Green, D. H. (2001). Experimental constraints on high pressure melting in subducted crust. Earth and Planetary Science Letters, 188(1), 149-168.

Hill, G. J., Caldwell, T. G., Heise, W., Chertkoff, D. G.,Bibby, H. M., Burgess, M. K., Cull, J. P.,Cas, R. A. (2009). Distribution of melt beneath Mount St Helens and Mount Adams inferred from magnetotelluric data. Nature Geoscience, 2(11), 785-789. 
Hirschmann, M. M., Baker, M. B., \& Stolper, E. M. (1998). The effect of alkalis on the silica content of mantlederived melts. Geochimica et Cosmochimica Acta, 62(5), 883-902.

Hoffmann-Rothe, A., Ritter, O., \& Haak, V. (2001). Magnetotelluric and geomagnetic modelling reveals zones of very high electrical conductivity in the upper crust of Central Java. Physics of the Earth and Planetary Interiors, 124(3), 131-151.

Holtz et al., 1995

Holtzman, B. K., Groebner, N. J., Zimmerman, M. E., Ginsberg, S. B., \&Kohlstedt, D. L. (2003). Stress-driven melt segregation in partially molten rocks. Geochemistry, Geophysics, Geosystems, 4(5).

Holtzman, B. K., King, D. S., \&Kohlstedt, D. L. (2012). Effects of stress-driven melt segregation on the viscosity of rocks.Earth and Planetary Science Letters, 359, 184-193.

Holtzman, B. K., \&Kohlstedt, D. L. (2007). Stress-driven melt segregation and strain partitioning in partially molten rocks: Effects of stress and strain. Journal of Petrology, 48(12), 2379-2406.

Ishimaru, S., Arai, S., Ishida, Y., Shirasaka, M., \&Okrugin, V. M. (2007). Melting and multi-stage metasomatism in the mantle wedge beneath a frontal arc inferred from highly depleted peridotite xenoliths from the Avacha volcano, southern Kamchatka. Journal of Petrology, 48(2), 395-433.

Jödicke, H., Jording, A., Ferrari, L., Arzate, J., Mezger, K., \&Rüpke, L. (2006). Fluid release from the subducted Cocos plate and partial melting of the crust deduced from magnetotelluric studies in southern Mexico: Implications for the generation of volcanism and subduction dynamics. Journal of Geophysical Research: Solid Earth (1978-2012), 111(B8).

Jousset, P., Pallister, J., Boichu, M., Buongiorno, M. F., Budisantoso, A., Costa, F., ... \& Lavigne, F. (2012). The 2010 explosive eruption of Java's Merapi volcano-A '100-year'event. Journal of volcanology and geothermal research, 241, 121-135.

Katz, R. F., Spiegelman, M., \&Holtzman, B. (2006). The dynamics of melt and shear localization in partially molten aggregates. Nature, 442(7103), 676-679.

Klemme, S., Blundy, J. D., \& Wood, B. J. (2002). Experimental constraints on major and trace element partitioning during partial melting of eclogite. Geochimica et Cosmochimica Acta, 66(17), 3109-3123.

Kohlstedt, D. L., \&Holtzman, B. K. (2009). Shearing melt out of the Earth: An experimentalist's perspective on the influence of deformation on melt extraction. Annual Review of Earth and Planetary Sciences, 37, 561593. 
Lowry, R. K., Henderson, P., \& Nolan, J. (1982). Tracer diffusion of some alkali, alkaline-earth and transition element ions in a basaltic and an andesitic melt, and the implications concerning melt structure.

Contributions to Mineralogy and Petrology, 80(3), 254-261.

Matsuno, T., Seama, N., Evans, R. L., Chave, A. D., Baba, K., White, A., ... \&Utada, H. (2010).Upper mantle electrical resistivity structure beneath the central Mariana subduction system.Geochemistry, Geophysics, Geosystems, 11(9).

Matsushima, N., Oshima, H., Ogawa, Y., Takakura, S., Satoh, H., Utsugi, M., \& Nishida, Y. (2001). Magma prospecting in Usu volcano, Hokkaido, Japan, using magnetotelluric soundings.Journal of Volcanology and Geothermal Research, 109(4), 263-277.

Maumus, J., Bagdassarov, N., \&Schmeling, H. (2005). Electrical conductivity and partial melting of mafic rocks under pressure.Geochimicaetcosmochimicaacta, 69(19), 4703-4718.

McGary, R. S., Evans, R. L., Wannamaker, P. E., Elsenbeck, J., \& Rondenay, S. (2014). Pathway from subducting slab to surface for melt and fluids beneath Mount Rainier. Nature, 511(7509), 338-340.

Muir, D. D., Blundy, J. D., Hutchinson, M. C., \& Rust, A. C. (2014).Petrological imaging of an active pluton beneath Cerro Uturuncu, Bolivia.Contributions to Mineralogy and Petrology, 167(3), 1-25.

Mysen, B. O., \& Acton, M. (1999). Water in $\mathrm{H}<\mathrm{sub}>2</$ sub $>$ O-saturated magma-fluid systems: solubility behavior in $\mathrm{K}<\mathrm{sub}>2</ \mathrm{sub}>\mathrm{O}-\mathrm{Al}<\mathrm{sub}>2</ \mathrm{sub}>\mathrm{O}<\mathrm{sub}>3</ \mathrm{sub}>-\mathrm{SiO}<\mathrm{sub}>2</$ sub $>-\mathrm{H}<\mathrm{sub}>2</$ sub $>$ O to $2.0 \mathrm{GPa}$ and $1300^{\circ} \mathrm{C}$. GeochimicaetCosmochimicaActa, 63(22), 3799-3815.

Mysen, B. O., \& Cody, G. D. (2004). Solubility and solution mechanism of $\mathrm{H}<\mathrm{sub}>2</ \mathrm{sub}>\mathrm{O}$ in alkali silicate melts and glasses at high pressure and temperature. GeochimicaetcosmochimicaActa, 68(24), 5113-5126.

Neumann, E. R., \&Wulff-Pedersen, E. (1997). The origin of highly silicic glass in mantle xenoliths from the Canary Islands. Journal of Petrology, 38(11), 1513-1539.

Ni, H., Behrens, H., \& Zhang, Y. (2009). Water diffusion in dacitic melt. GeochimicaetCosmochimicaActa, 73(12), 3642-3655.

Ni, H., Keppler, H., \& Behrens, H. (2011). Electrical conductivity of hydrous basaltic melts: implications for partial melting in the upper mantle. Contributions to Mineralogy and Petrology, 162(3), 637-650.

Nowak, M., \& Behrens, H. (1997). An experimental investigation on diffusion of water in haplogranitic melts. Contributions to Mineralogy and Petrology, 126(4), 365-376. 
Ogawa, Y., Matsushima, N., Oshima, H., Takakura, S., Utsugi, M., Hirano, K., ... \&Doi, T. (1998).A resistivity cross-section of Usu volcano, Hokkaido, Japan, by audiomagnetotelluric soundings.Earth Planets Space, $50(4), 339-346$.

Ohlhorst, S., Behrens, H., \& Holtz, F. (2001). Compositional dependence of molar absorptivities of near-infrared $\mathrm{OH}$-and $\mathrm{H}<\mathrm{sub}>2</ \mathrm{sub}>\mathrm{O}$ bands in rhyolitic to basaltic glasses. Chemical Geology, 174(1), 5-20.

Pallister, J. S., Thornber, C. R., Cashman, K. V., Clynne, M. A., Lowers, H. A., Mandeville, C. W., Brownfiel, I. K, Meeker, G. P. (2008). Petrology of the 2004-2006 Mount St. Helens lava dome-implications for magmatic plumbing and eruption triggering. US Geological Survey professional paper, (1750), 647-702.

Patro, P. K., \& Egbert, G. D. (2008). Regional conductivity structure of Cascadia: Preliminary results from 3D inversion of USArray transportable array magnetotelluric data. Geophysical Research Letters, 35(20).

Peacock, S. A. (1990). Fluid processes in subduction zones. Science, 248(4953), 329-337.

Peacock, S. M., Rushmer, T., \& Thompson, A. B. (1994).Partial melting of subducting oceanic crust.Earth and planetary science letters, 121(1), 227-244.

Pfeiffer, T. (1998). Viscosities and electrical conductivities of oxidic glass-forming melts.Solid State Ionics, 105(1), 277-287.

Poe, B. T., Romano, C., Varchi, V., Misiti, V., \&Scarlato, P. (2008). Electrical conductivity of a phonotephrite from Mt. Vesuvius: The importance of chemical composition on the electrical conductivity of silicate melts. Chemical Geology, 256(3), 193-202.

Poe, B. T., Romano, C., Di Genova, D., Behrens, H., \&Scarlato, P. (2012). Mixed electrical conduction in a hydrous pantellerite glass.Chemical Geology, 320, 140-146.

Pommier, A., Gaillard, F., Pichavant, M., \&Scaillet, B. (2008). Laboratory measurements of electrical conductivities of hydrous and dry Mount Vesuvius melts under pressure. Journal of Geophysical Research: Solid Earth (1978-2012), 113(B5).

Pommier, A., Gaillard, F., Malki, M., \&Pichavant, M. (2010). Methodological re-evaluation of the electrical conductivity of silicate melts. American Mineralogist, 95(2-3), 284-291.

Pommier, A., \& Le-Trong, E. (2011).“SIGMELTS”: A web portal for electrical conductivity calculations in geosciences. Computers \& Geosciences, 37(9), 1450-1459.

Presnall, D. C., Simmons, C. L., \&Porath, H. (1972). Changes in electrical conductivity of a synthetic basalt during melting. Journal of Geophysical Research, 77(29), 5665-5672. 
Pritchard, M. E., \& Simons, M. (2002). A satellite geodetic survey of large-scale deformation of volcanic centres in the central Andes.Nature, 418(6894), 167-171.

Prouteau, G., Scaillet, B., Pichavant, M., \& Maury, R. C. (1999). Fluid-present melting of ocean crust in subduction zones. Geology, 27(12), 1111-1114.

Prouteau, G., Scaillet, B., Pichavant, M., \& Maury, R. (2001). Evidence for mantle metasomatism by hydrous silicic melts derived from subducted oceanic crust. Nature, 410(6825), 197-200.

Prouteau, G., \&Scaillet, B. (2003). Experimental constraints on the origin of the 1991 Pinatubo dacite.Journal of Petrology, 44(12), 2203-2241.

Rapp, R. P., Shimizu, N., Norman, M. D., \& Applegate, G. S. (1999). Reaction between slab-derived melts and peridotite in the mantle wedge: experimental constraints at $3.8 \mathrm{GPa}$. Chemical Geology, 160(4), 335356.Roberts, J. J., \&Tyburczy, J. A. (1991). Frequency dependent electrical properties of polycrystalline olivine compacts.Journal of Geophysical Research: Solid Earth (1978-2012), 96(B10), 16205-16222.

Roberts, J. J., \&Tyburczy, J. A. (1994). Frequency dependent electrical properties of minerals and partialmelts.Surveys in Geophysics, 15(2), 239-262.

Roberts, J. J., \&Tyburczy, J. A. (1999). Partial- melt electrical conductivity: Influence of melt composition. Journal of Geophysical Research: Solid Earth (1978-2012), 104(B4), 7055-7065.

Rosell, O., Martí, A., Marcuello, À., Ledo, J., Queralt, P., Roca, E., \&Campanyà, J. (2011). Deep electrical resistivity structure of the northern Gibraltar Arc (western Mediterranean): evidence of lithospheric slab break-off. Terra Nova, 23(3), 179-186.

Rutherford, M. J., Sigurdsson, H., Carey, S., \& Davis, A. (1985). The May 18, 1980, eruption of Mount St. Helens: 1. Melt composition and experimental phase equilibria. Journal of Geophysical Research: Solid Earth (1978-2012), 90(B4), 2929-2947.

Scaillet, B., \& Prouteau, G. (2001). Oceanic slab melting and mantle metasomatism. Science progress, 84(4), 335-354

Schiano, P., Clocchiatti, R., Shimizu, N., Maury, R. C., Jochum, K. P., \& Hofmann, A. W. (1995). Hydrous, silica-rich melts in the sub-arc mantle and their relationship with erupted arc lavas. Nature, 377(6550), 595600.

Schilling, F. R., Trumbull, R. B., Brasse, H., Haberland, C., Asch, G., Bruhn, D., ... \&Vietor, T. (2006). Partial melting in the Central Andean crust: a review of geophysical, petrophysical, and petrologic evidence. In The Andes (pp. 459-474).Springer Berlin Heidelberg. 
Schmeling, H. (1985). Numerical models on the influence of partial melt on elastic, anelastic and electric properties of rocks. Part I: elasticity and anelasticity. Physics of the earth and planetary interiors, 41(1), 3457.

Schwarz, G., \&Krüger, D. (1997). Resistivity cross section through the southern central Andes as inferred from magnetotelluric and geomagnetic deep soundings. Journal of Geophysical Research: Solid Earth (19782012), 102(B6), 11957-11978.

Sen, C., \& Dunn, T. (1994). Dehydration melting of a basaltic composition amphibolite at 1.5 and 2.0 GPa: implications for the origin of adakites. Contributions to Mineralogy and Petrology, 117(4), 394-409.

Shimizu, Y., Arai, S., Morishita, T., Yurimoto, H., \&Gervilla, F. (2004). Petrochemical characteristics of felsic veins in mantle xenoliths from Tallante (SE Spain): an insight into activity of silicic melt within the mantle wedge. Transactions of the Royal Society of Edinburgh: Earth Sciences, 95(1-2), 265-276.

Sifre, D., Gardes, E., Massuyeau, M., Hashim, L., Hier-Majumder, S., Gaillard, F., (in press).The electrical conductivity during incipient melting in the oceanic low velocity zone, Nature.

Smith, D. R., \&Leeman, W. P. (1987). Petrogenesis of Mount St. Helens dacitic magmas.Journal of Geophysical Research: Solid Earth (1978-2012), 92(B10), 10313-10334.

Soyer, W., \&Unsworth, M. (2006). Deep electrical structure of the northern Cascadia (British Columbia, Canada) subduction zone: Implications for the distribution of fluids. Geology, 34(1), 53-56.

Sparks, R. S. J., Folkes, C. B., Humphreys, M. C., Barfod, D. N., Clavero, J., Sunagua, M. C., ... \& Pritchard, M. E. (2008).Uturuncu volcano, Bolivia: Volcanic unrest due to mid-crustal magma intrusion. American Journal of Science, 308(6), 727-769.

Stephen, J., Dillenburg, G. (1995). Impedance spectra of hot, dry silicate minerals and rock: Qualitative interpretation of spectra. American Mineralogist, 80, 46-64.

Stern, C. R., \& Wyllie, P. J. (1981). Phase relationships of I-type granite with H2O to 35 kilobars: The Dinkey Lakesbiotite-granite from the Sierra Nevada Batholith. Journal of Geophysical Research: Solid Earth (19782012), 86(B11), 10412-10422.

Sutton, A. N., Blake, S., Wilson, C. J.,Charlier, L. A. B. (2000). Late Quaternary evolution of a hyperactive rhyolite magmatic system: Taupo volcanic centre, New Zealand. Journal of the Geological Society, 157(3), 537-552. 
Ten Grotenhuis, S. M., Drury, M. R., Spiers, C. J., \& Peach, C. J. (2005). Melt distribution in olivine rocks based on electrical conductivity measurements. Journal of Geophysical Research: Solid Earth (1978-2012), 110(B12).

Tomiya, A. (1997). The depth of a magma chamber as revealed by high-pressure melting experiments, in thermal structures of the lithosphere, in Japanese Gekkan-chikyu, 19, 720-724

Tomiya, A., \& Takahashi, E. (2005). Evolution of the magma chamber beneath Usu Volcano since 1663: a natural laboratory for observing changing phenocryst compositions and textures. Journal of Petrology, 46(12), 2395-2426.

Tyburczy, J. A., \&Waff, H. S. (1983). Electrical conductivity of molten basalt and andesite to 25 kilobars pressure: Geophysical significance and implications for charge transport and melt structure. Journal of Geophysical Research: Solid Earth (1978-2012), 88(B3), 2413-2430.

Tyburczy, J. A., \&Waff, H. S. (1985). High pressure electrical conductivity in naturally occurring silicate liquids. Geophysical Monograph Series, 31, 78-87.

Tyburczy, J. A., \&Fisler, D. K. (1995). Electrical properties of minerals and melts.AGU Reference Shelf, 2, 185 208.

Unsworth, M. J., Jones, A. G., Wei, W., Marquis, G., Gokarn, S. G., Spratt, J. E., ... \& Roberts, B. (2005). Crustal rheology of the Himalaya and Southern Tibet inferred from magnetotelluric data. Nature, 438(7064), $78-81$

Unsworth MJ, MJ Comeau, F Ticona, Distribution of melt beneath the Altiplano-Puna volcanic complex from magnetotelluric data, contributed paper V13B-2601 at American Geophysical Union Fall Meeting, San Francisco, December 9-13, 2013.

Waff, H. S., \& Weill, D. F. (1975). Electrical conductivity of magmatic liquids: effects of temperature, oxygen fugacity and composition. Earth and Planetary Science Letters, 28(2), 254-260.

Worzewski, T., Jegen, M., Kopp, H., Brasse, H., \& Castillo, W. T. (2011). Magnetotelluric image of the fluid cycle in the Costa Rican subduction zone. Nature Geoscience, 4(2), 108-111.

Wulff-Pedersen, E., Neumann, E. R., \& Jensen, B. B. (1996). The upper mantle under La Palma, Canary Islands: formation of $\mathrm{Si}-\mathrm{K}-\mathrm{Na}$-rich melt and its importance as a metasomatic agent. Contributions to Mineralogy and Petrology, 125(2-3), 113-139. 
Wysoczanski, R., \&Tani, K. (2006). Spectroscopic FTIR imaging of water species in silicic volcanic glasses and melt inclusions: an example from the Izu-Bonin arc. Journal of volcanology and geothermal research, $156(3), 302-314$

Yoshino, T., Laumonier, M., McIsaac, E., \& Katsura, T. (2010). Electrical conductivity of basaltic and carbonatite melt-bearing peridotites at high pressures: Implications for melt distribution and melt fraction in the upper mantle. Earth and Planetary Science Letters, 295(3), 593-602.

Yoshino, T., McIsaac, E., Laumonier, M., \& Katsura, T. (2012). Electrical conductivity of partial molten carbonate peridotite. Physics of the Earth and Planetary Interiors, 194, 1-9.

Zhang, Y., \& Behrens, H. (2000). $\mathrm{H}_{2} \mathrm{O}$ diffusion in rhyolitic melts and glasses. Chemical Geology, 169(1), 243262.

Zhang, Y., Stolper, E. M., \&Wasserburg, G. J. (1991). Diffusion of water in rhyolitic glasses. Geochimica et Cosmochimica Acta, 55(2), 441-456. 

details.

\section{CAPTIONS}

Figure 1: profile of water concentration in the 3 hydrated syntheses obtained by FTIR over 1.3 to $2.0 \mathrm{~mm}$.

Figure 2: $3 / 4$ assembly used for electrical conductivity measurements in piston cylinder.

Figure 3: Impedance spectra represented in the Nyquist plan (Z', Z') for the dacite. A) At low temperature and relatively large resistance, the frequency range investigated defines a semicircle corresponding to the electrical response of the sample $(\mathrm{R}<\mathrm{Z}$ ') and a linear part ( $\mathrm{R}$ $>Z^{\prime}$ ) due to the effect of the interface between the sample and the electrodes. At higher temperatures (B \& C), corresponding to lower resistance values, no impedance arcs were observed; the electrical response is characterised by the decrease and the increase of Z" (B), and by an increase of Z" crossing Z" $=0$. The arrow indicates the resistance $\mathrm{R}$ of the sample in each type of spectra.

Figure 4: water concentration in the run products according to their pressure, compared with the starting glasses. No significant water loss was noticed.

Figure 5: Arrhenius diagram of the electrical conductivity of UTU41B-0e and UTU41B-7c versus $1 /$ Temperature $(\mathrm{K})$ along heating and cooling paths. The black arrow indicates the temperature at which the conductivity is reproduced during the next temperature paths. The solid line is the fit of experimental data at temperature higher than $950^{\circ} \mathrm{C}$. See the text for 
Figure 6: Arrhenius diagram of the electrical conductivity of dry and hydrous dacitic melts versus 1000/Temperature in K (open symbols). The legend indicates the water contents of the dacite (numbers in color) and the pressure of the experiments (black number). The fits of the models for dry and hydrous dacitic compositions at various pressures using equations 1, 5 and 7 and the fitting values in Table 3 are represented by curves with the same color code.

Figure 7: Activation Energy (A) and pre-exponential factor (B) versus the pressure. Same legend in $\mathrm{A}$ and $\mathrm{B}$.

Figure 8: $\mathrm{Na}, \mathrm{H}^{+}$diffusivities determined from electrical conductivity measurements for the four dacitic melts with different water contents (number on the right of curves), and $\mathrm{H} 2 \mathrm{O}$ diffusivity reported by Zhang \& Behrens (2000). The Na diffusivities are compared with values from the literature (Lowry et al., 1982; Henderson et al., 1985).

Figure 9: $\log$ of conductivity versus water content of the dacite at 850 (A) and $1000^{\circ} \mathrm{C}$ (B) compared with data from the literature. Rhyolite is from Gaillard et al. (2004), Sigmelts is a model simulating the dacitic composition (Pommier\& Le Trong, 2011) and metapelite is from Hashim et al. (2013).

Figure 10: Electrical conductivities of Altiplano-Puna Magma Body (Bolivia, A), Usu (Japan, B), Taupo (New Zealand, C), Merapi (Indonesia, D) and St Helens (Washington state, E) areas from magnetotelluric survey (grey rectangles) and corresponding conductivities from the model. Conductivities are represented until water saturation $\left(\mathrm{H}_{2} \mathrm{O}\right.$ sat.) estimated from the conductive body depth. Solid lines are calculated conductivity from the model of this study, 
49 the thick and thin ones being respectively the melt and a mixture a melt + crystal 50 conductivities. See the text for details.

51

52 Figure 11: Electrical conductivity of the cold mantle wedge percolated by a small fraction of 53 dacite. MT data are not specific to any particular melt fraction and come from Booker et al., 542004 (Argentina), Soyer\&Unsworth, 2006 (Northern Cascades), Jodick et al., 2006 (Mexico), 55 Patro\& Egbert, 2008 (Cascades), Brasse et al., 2009 Worzewski et al., 2011, (Costa Rica); 56 Matsuno et al., 2010 (Mariana); Rosell et al., 2011 (Alboran). 


\begin{tabular}{ccccccccc}
\hline $\mathrm{SiO}_{2}$ & $\mathrm{TiO}_{2}$ & $\mathrm{Al}_{2} \mathrm{O}_{3}$ & $\mathrm{FeO}$ & $\mathrm{MnO}$ & $\mathrm{MgO}$ & $\mathrm{CaO}$ & $\mathrm{Na}_{2} \mathrm{O}$ & $\mathrm{K}_{2} \mathrm{O}$ \\
\hline 67.93 & 0.91 & 15.30 & 4.24 & 0.07 & 1.45 & 3.31 & 2.09 & 4.69 \\
1.33 & 0.21 & 0.65 & 0.60 & 0.08 & 0.20 & 0.33 & 0.10 & 0.21 \\
\hline
\end{tabular}

57 Table 1: Chemical composition normalized to $100 \%$ of the volatile-free starting dacite after melting at $58 \quad \mathbf{1 4 5 0}^{\circ} \mathrm{C}$ and 1 atm.

59

60

\begin{tabular}{llcccccc}
\hline \# Exp. & $\begin{array}{l}\text { Starting } \\
\text { Material }\end{array}$ & $\mathrm{P}(\mathrm{GPa})$ & $\mathrm{T}^{\circ} \mathrm{C}$ range & $\begin{array}{c}\text { Duration } \\
(\mathrm{h})\end{array}$ & $\begin{array}{c}\text { Water content } \\
(\mathrm{wt} \%)\end{array}$ & $\begin{array}{c}\text { Ea } \\
(\mathrm{kJ} / \mathrm{mol})\end{array}$ & $\begin{array}{c}\text { Log } \sigma 0 \\
(\mathrm{~S} . \mathrm{m}-1)\end{array}$ \\
\hline UTU41B-0g & UTU41B-dry & 0.30 & $400-1214$ & 7 & - & 88.3 & 2.6 \\
UTU41B-0e & UTU41B-dry & 0.49 & $400-1211$ & 24 & - & 88.2 & 2.5 \\
UTU41B-0i & UTU41B-dry & 2.78 & $400-1350$ & 2 & - & 96.4 & 2.7 \\
\hline UTU41B-3d & UTU41B-3 & 0.15 & $500-1107$ & 2.5 & 3.25 & 75.8 & 2.8 \\
UTU41B-3c & UTU41B-3 & 0.52 & $400-1218$ & 3 & 3.28 & 79.1 & 2.8 \\
UTU41B-3f & UTU41B-3 & 2.78 & $400-1271$ & 2.5 & 3.29 & 89.6 & 3.3 \\
\hline UTU41B-7c & UTU41B-7 & 0.56 & $400-1237$ & 2.5 & 7.09 & 61.7 & 3.0 \\
UTU41B-7e & UTU41B-7 & 2.04 & $400-1211$ & 2 & 7.11 & 84.0 & 3.5 \\
UTU41B-7d & UTU41B-7 & 3.00 & $400-1204$ & 2 & 7.03 & 92.6 & 3.8 \\
\hline UTU41B-12 & UTU41B-12 & 3.00 & $400-1219$ & 2 & 11.76 & 91.0 & 4.2 \\
\hline
\end{tabular}

61 Table 2: Experimental details.

62

\begin{tabular}{|c|c|c|c|}
\hline & ameter & & value \\
\hline \multirow{4}{*}{$\sigma_{0}$} & \multirow{4}{*}{$P$ dep. } & a & -0.064 \\
\hline & & $b$ & 5.96 \\
\hline & & C & 1.06E-05 \\
\hline & & $d$ & 2.49E-05 \\
\hline \multirow{4}{*}{$\mathrm{Ea}$} & \multirow{2}{*}{$H$} & e & -6146 \\
\hline & & $f$ & 88440 \\
\hline & \multirow{2}{*}{$\Delta V$} & $g$ & 0.176 \\
\hline & & $\mathrm{h}$ & 0.388 \\
\hline
\end{tabular}

63

Table 3: fitted parameters of the electrical model of dry and hydrous dacitic melts.

64 


\section{Supplementary information}

\section{Experimental Methods}

\section{Water conservation}

First experiments conducted at $0.5 \mathrm{GPa}$ showed that the initial porosity of the $\mathrm{MgO}$ and the frictional force result in a too low effective pressure on the sample which led to its rapid (few tens of seconds) dehydration. Therefore, in order to maintain the water content of our samples (in the form of both drilled cylinders and powders), the pressure was largely increased above dwell pressure before sample heating. Typically, for experiments conducted at $0.5 \mathrm{GPa}$, the pressure was first set to $1.2 \mathrm{GPa}$. Then, the temperature was increase until $\sim 400^{\circ} \mathrm{C}$, and the pressure was slightly released up to the target pressure $(0.5 \mathrm{GPa})$. Once the target pressure was reached, the sample was heated up with adjustment of the pressure variation related to dilatation of the sample and reduction of the porosity.

\section{Sample's resistance acquisition}

The furnace power was set manually by a proportional-integrative-derivative controller. New acquisition of the sample resistance followed a change of the furnace power and a lap time to get a stable temperature. The temperature was checked before and after the sample resistance acquisition and in between, i.e. during $\sim 30$ seconds, a constant power was applied without temperature measurements. We observed that the temperature did not change by more than $\sim 5^{\circ} \mathrm{C}$ during impedance acquisition. In the few cases where more important T-deviations were observed, the measurements were repeated until a stable temperature was observed (see also "Stability of experimental conditions and reproducibility of EC measurements").

$\underline{\text { Range of measureable resistance and error on measurements }}$

To characterized the range of resistance allowed with such a setup, the sample was replaced by a resistive alumina cylinder and a conductive nickel plug, leading to measured resistances $\mathrm{R}_{\mathrm{Al}}>10^{7}$ and $\mathrm{R}_{\mathrm{Ni}}<10^{-2} \mathrm{ohm}$ respectively (Sifre et al., 2014). It was then concluded that the dacitic sample was the only conductive path in the experimental $\mathrm{P}$, T conditions and one can measure impedance as low as $10^{-2} \mathrm{ohm}$.

In some cases, the sample did not maintain a perfect cylindrical shape, and average length and diameter were used to calculate the geometrical factor. The variation in the sample length results in the deviation of the geometric factor of $2 \%$ maximum, Horizontal cracks resulting in sample relaxation during unloading were corrected by removing the cumulated crack thickness to the total sample length. We neglected other eventual variation of sample dimension, assuming it was the same for and after experiments.

\section{Stability of experimental conditions and reproducibility of EC measurements}

Between heating and cooling paths, the reproducibility of the measurements was tested by acquiring data at constant P-T conditions (Fig. SI1). The conductivity is remarkably stable in the first 8 hours, whereas it gently changed for vey long run durations (time $>8 \mathrm{~h}$ ). However, the increase of the conductivity between 9 and $13 \mathrm{~h}$ is associated to a regular increase of the temperature and the EC values range perfectly between the ones obtained during heating and cooling cycles (Fig. SI1 A \& B). The last series of measurements (time $>14 \mathrm{~h}$ ) shows an oscillation with time, being associated to oscillation in temperature. Therefore, conductivity measurements are well reproducible over long duration (hours), indicating negligible changes of the sample when exposed to the P-T-fO2 conditions of the piston cylinder (see Pommier et al. (2010) for the impact of $\mathrm{fO}_{2}$ on conductivity).

\section{Textural observations}

The sample dimensions (diameter and length) were precisely determined from SEM images to calculate the geometrical factor. The gap between the internal electrode and the thermocouple or the lower alumina disk and the horizontal fractures both result from the thermal contraction and from 
the final decompression (and extraction) of the whole assembly (Fig. SI2). No significant melt segregation was observed, except in the experiments UTU41B-0e and UTU41B-3c where a small fraction of the melt escaped in the $\mathrm{MgO}$ porosity (over no more than 100 micrometers) and beneath the lower alumina disk over few hundreds of micrometres respectively (Fig. SI2). Then, sample only suffered from a small decrease of the diameter and the length, more pronounced in the sample made of powder (e.g. compare Fig. SI2 A \& C, sample made of cylindrical and powder glasses respectively).

After experiments, the dry samples remained free of crystals. It is not the case of most of the hydrous experiments that developed crystals of amphibole, with occasional pyroxenes and oxides. The crystal fraction basically increases with the water content from $\sim 2 \%\left(\mathrm{H}_{2} \mathrm{O}=3.3 \mathrm{wt} . \%\right)$ up to $12 \%$ in volume in the most hydrated samples. Despite their relatively large size (several hundreds of micrometres, and aggregates of more than a millimetre), the shape of these crystals suggests that they are quench crystals resulting from the cooling of the sample. The presence of such crystals does not seem to affect the water concentration determination; FTIR analyses were preferentially made in crystal-free area. In addition, chemical analyses and elemental mapping did not evidence any chemical contamination from the surrounding $\mathrm{MgO}$, alumina disks nor the platinum electrodes during the duration of the experiments.

\section{Activation Energy of sodium diffusion in dacitic melts}

We calculated the activation energy (Ea) of $\mathrm{Na}$ diffusion of the dacitic melts with the different water contents investigated here, assuming that $\mathrm{Na}$ remains the dominant charge carrier even in water-rich melts. Ea of $\mathrm{Na}$ diffusion ranges from 64 to $110 \mathrm{~kJ}$, and is therefore slightly higher than activation energy of electrical conductivity obtained in the same experimental conditions, in particular at high pressure (62 to $96 \mathrm{~kJ}$; Fig. SI3).

\section{References of Supplementary information}

Pommier, A., Gaillard, F., Malki, M., \& Pichavant, M. (2010). Methodological re-evaluation of the electrical conductivity of silicate melts. American Mineralogist, 95(2-3), 284-291.

Sifre, D., Gardes, E., Massuyeau, M., Hashim, L., Hier-Majumder, S., Gaillard, F., (in press).The electrical conductivity during incipient melting in the oceanic low velocity zone, Nature.

\section{Caption of Supplementary Information figures}

Figure SI1: A) Electrical conductivity along heating and cooling paths, with intercalated steps at constant temperature to test the reproducibility of the measure. B) Electrical conductivity of the four constant temperature steps versus the time.

Figure SI2: SEM images showing the sample shape after experiments. The geometrical factor G was calculated after the determination of sample dimensions corrected of the decompression fractures. Crystals are frequently observed in hydrous samples. Abbreviations : alumina ( $\mathrm{Al}$ ), amphibole (Amp), glass (gl), oxide (ox), (Pt), pyroxene (Px), thermocouple (Tc).

Figure SI3: Calculated activation energies of $\mathrm{Na}$ diffusion of the four different melts and comparison with the activation energies for electrical conductivity $(\sigma)$. 

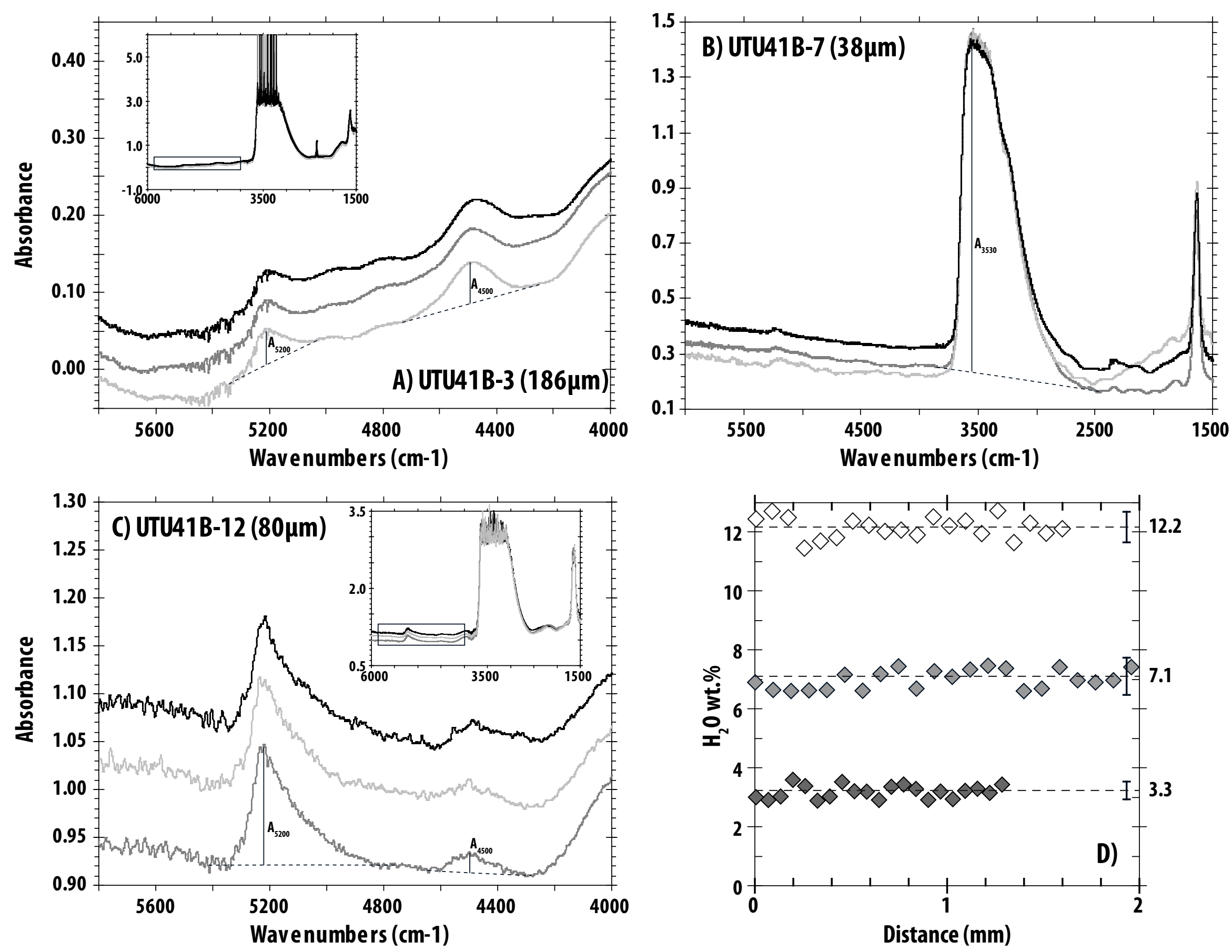

Laumonier et al., Fig. 1 


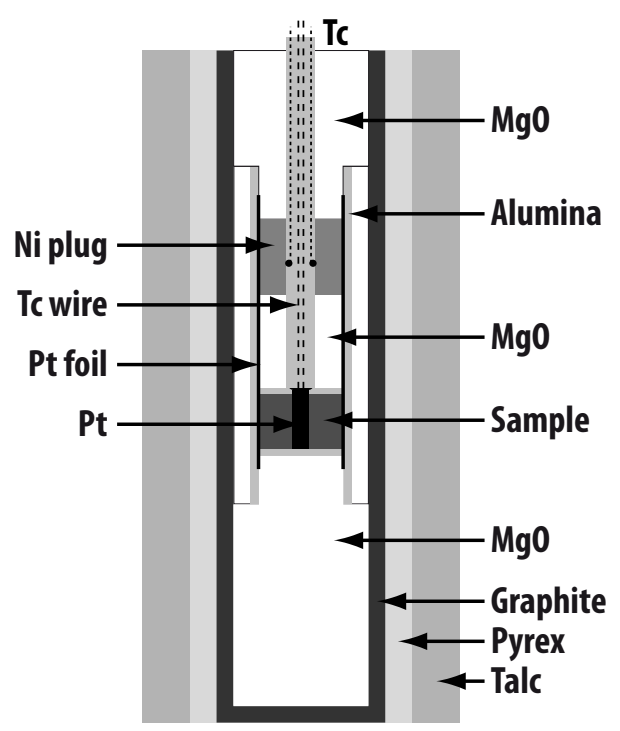

Laumonier et al., Fig. 2 


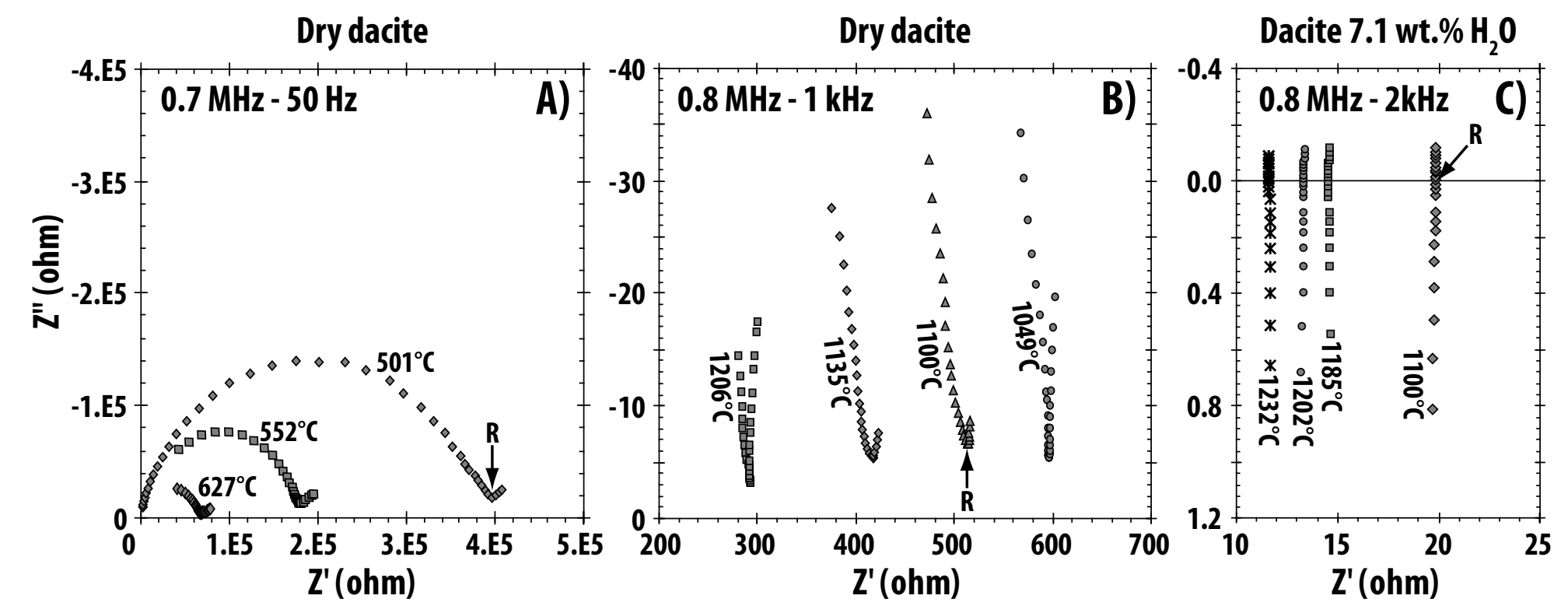

\section{Laumonier et al., Fig. 3}




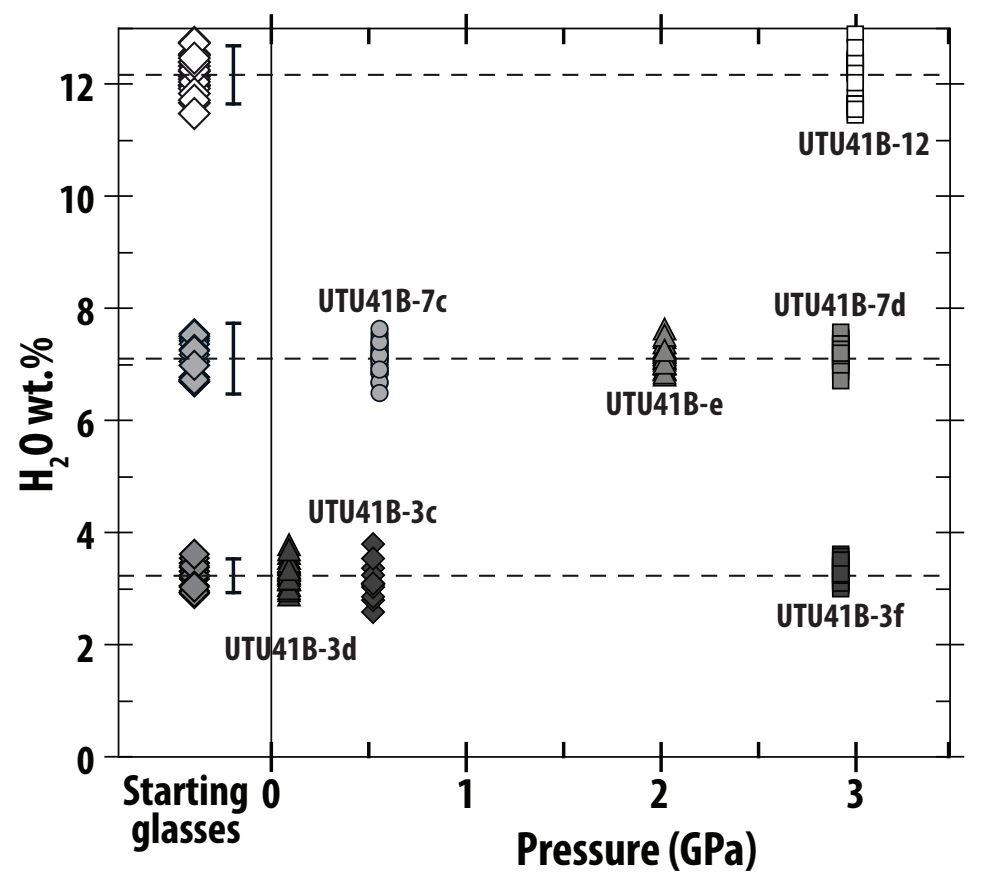

Laumonier et al., Fig. 4 


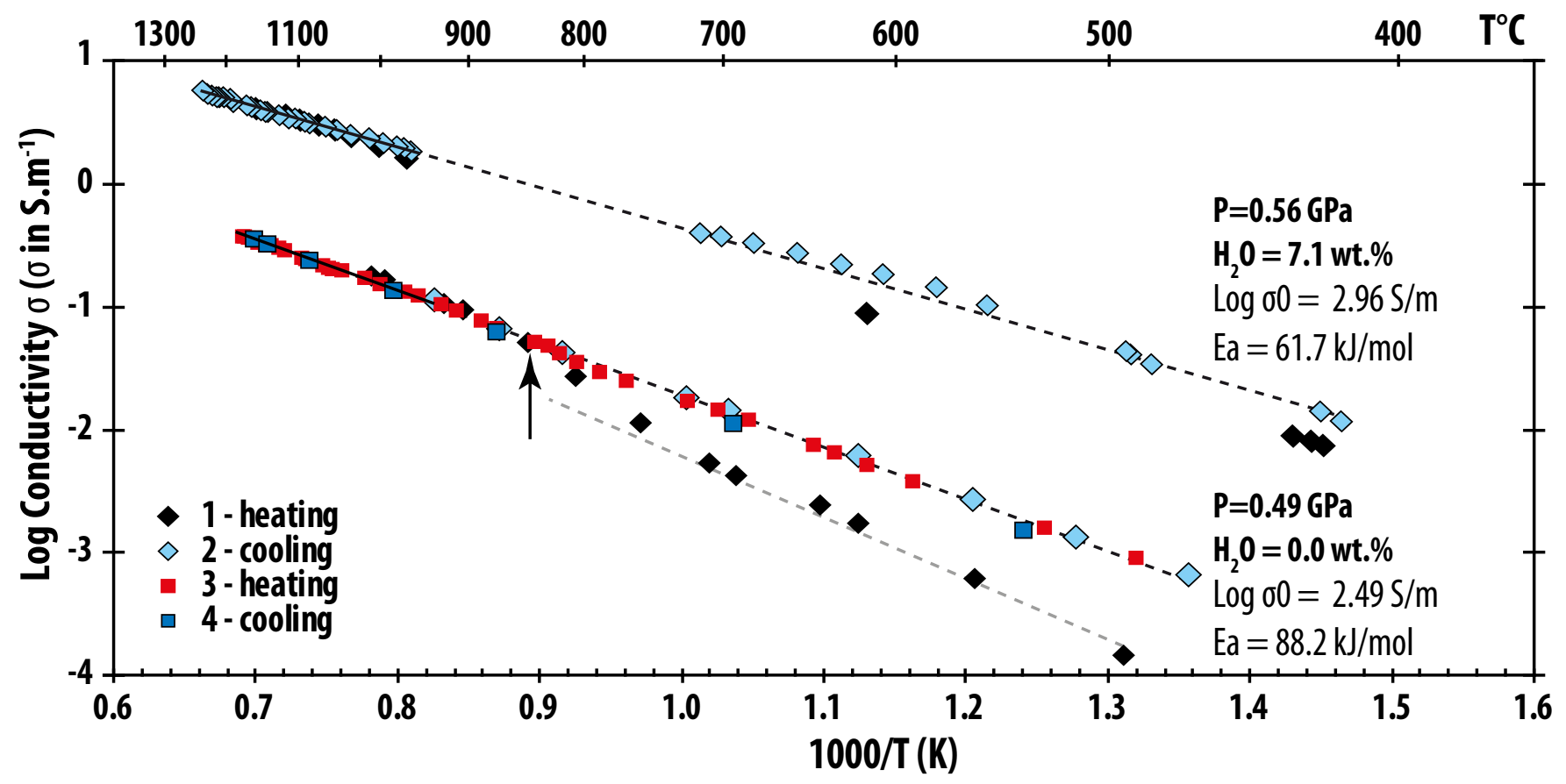

Laumonier et al., Fig. 5 


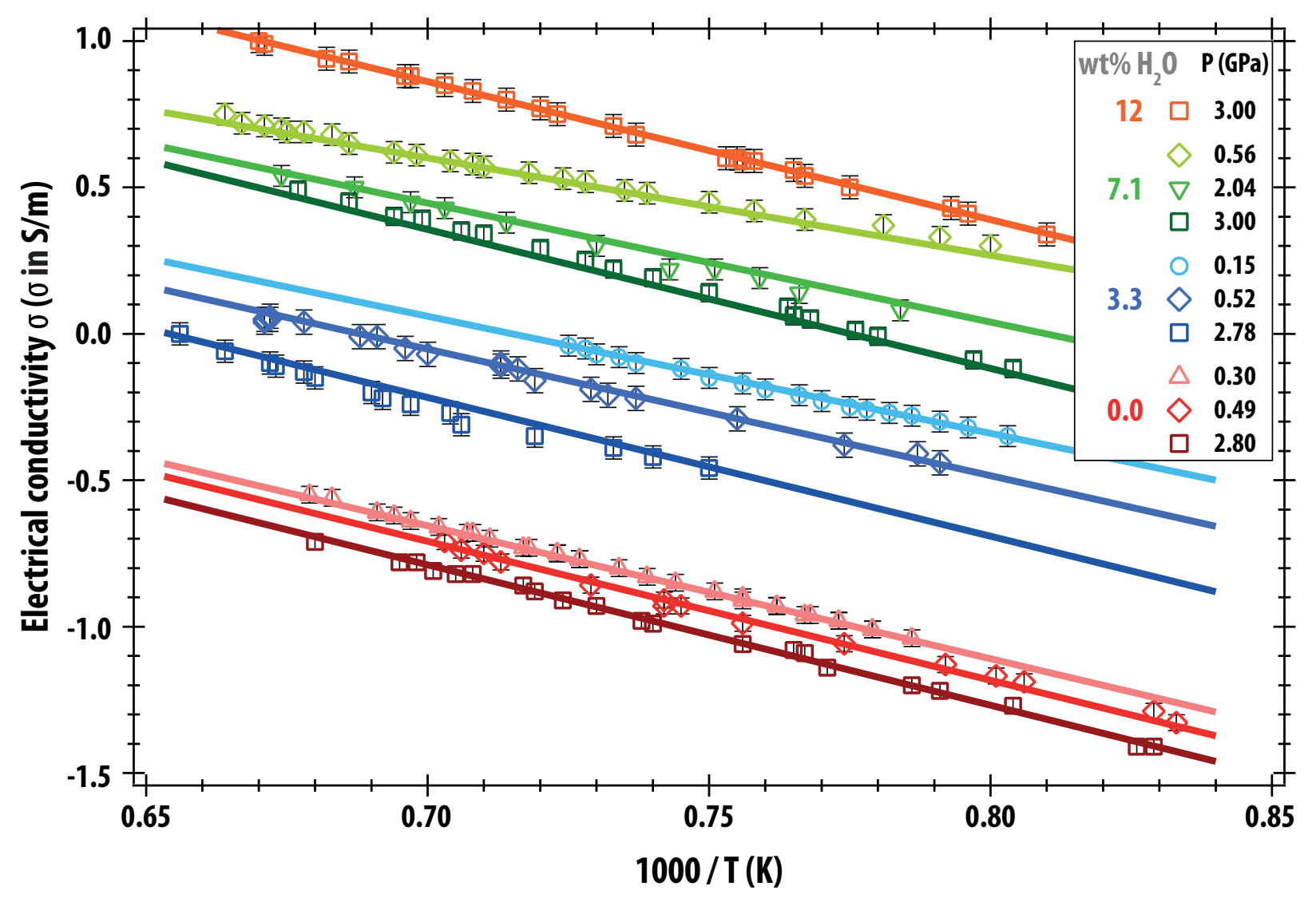

Laumonier et al., Fig. 6 

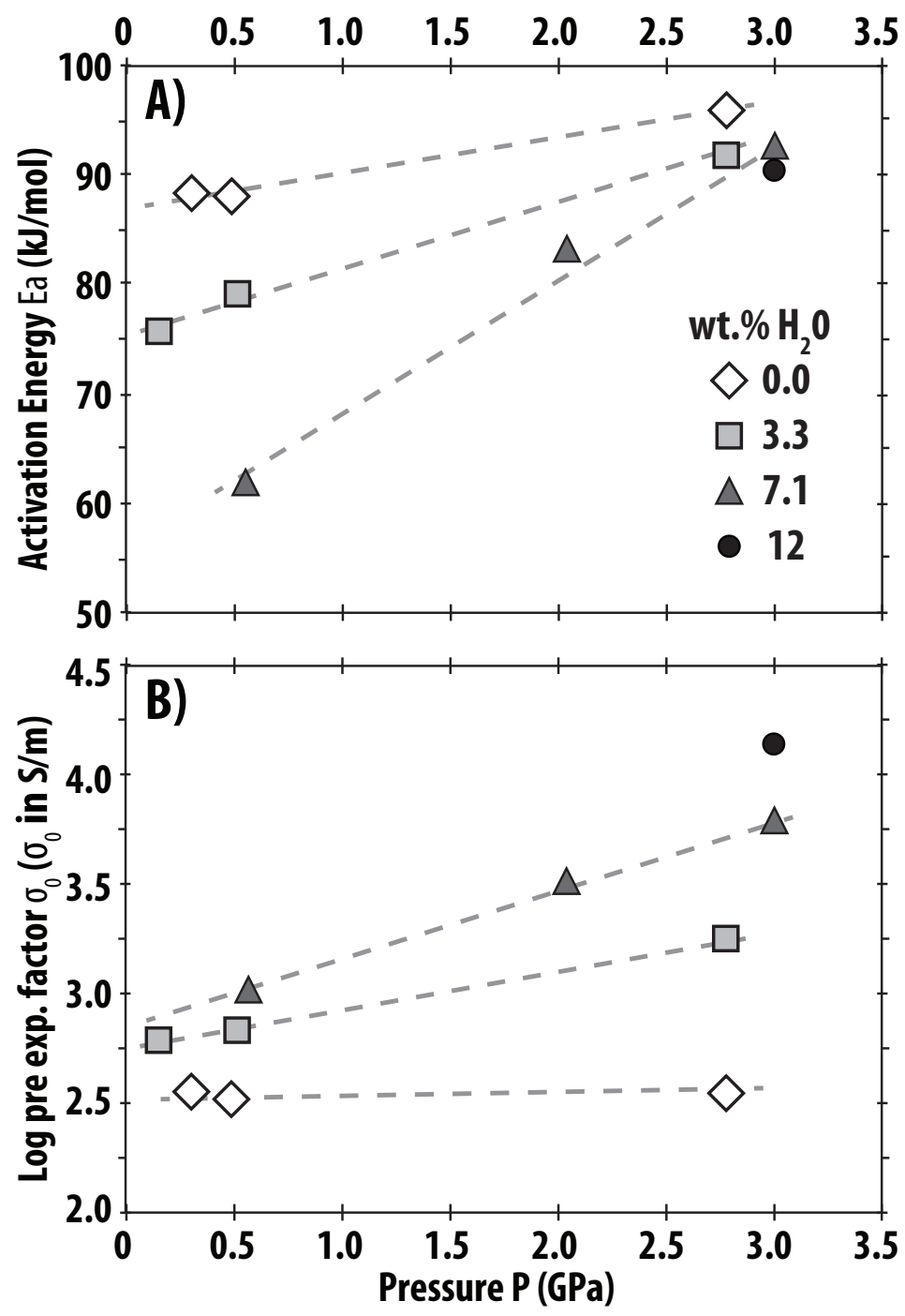

Laumonier et al., Fig. 7 


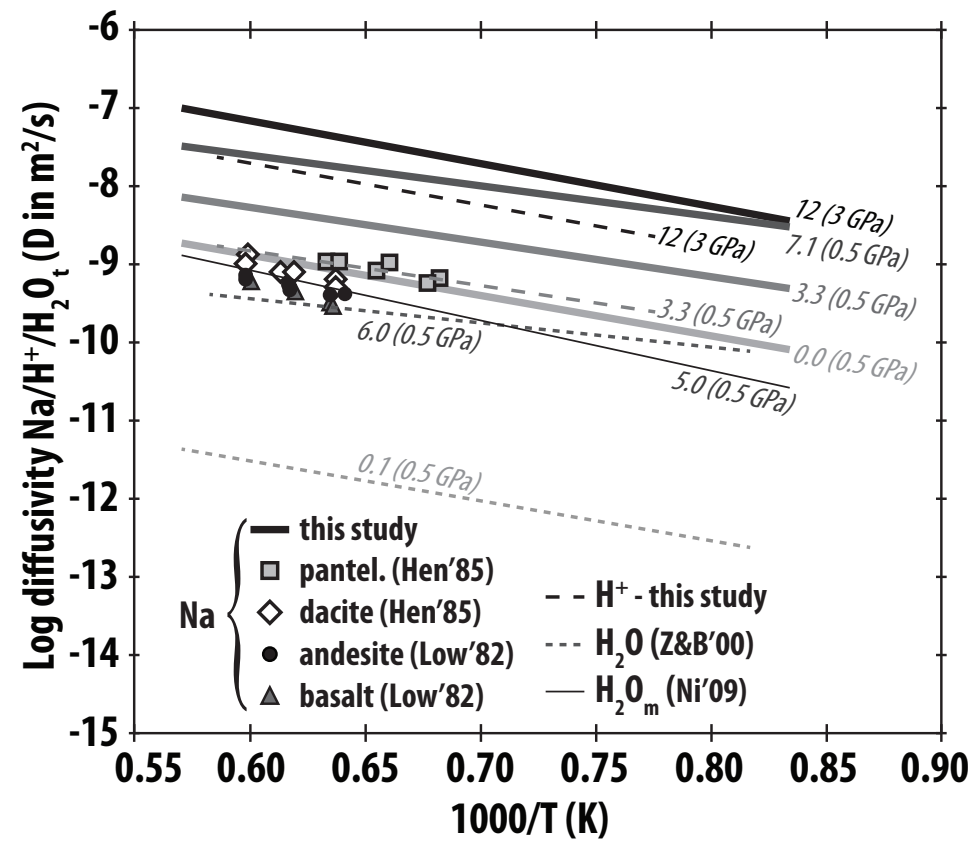

Laumonier et al., Fig. 8 


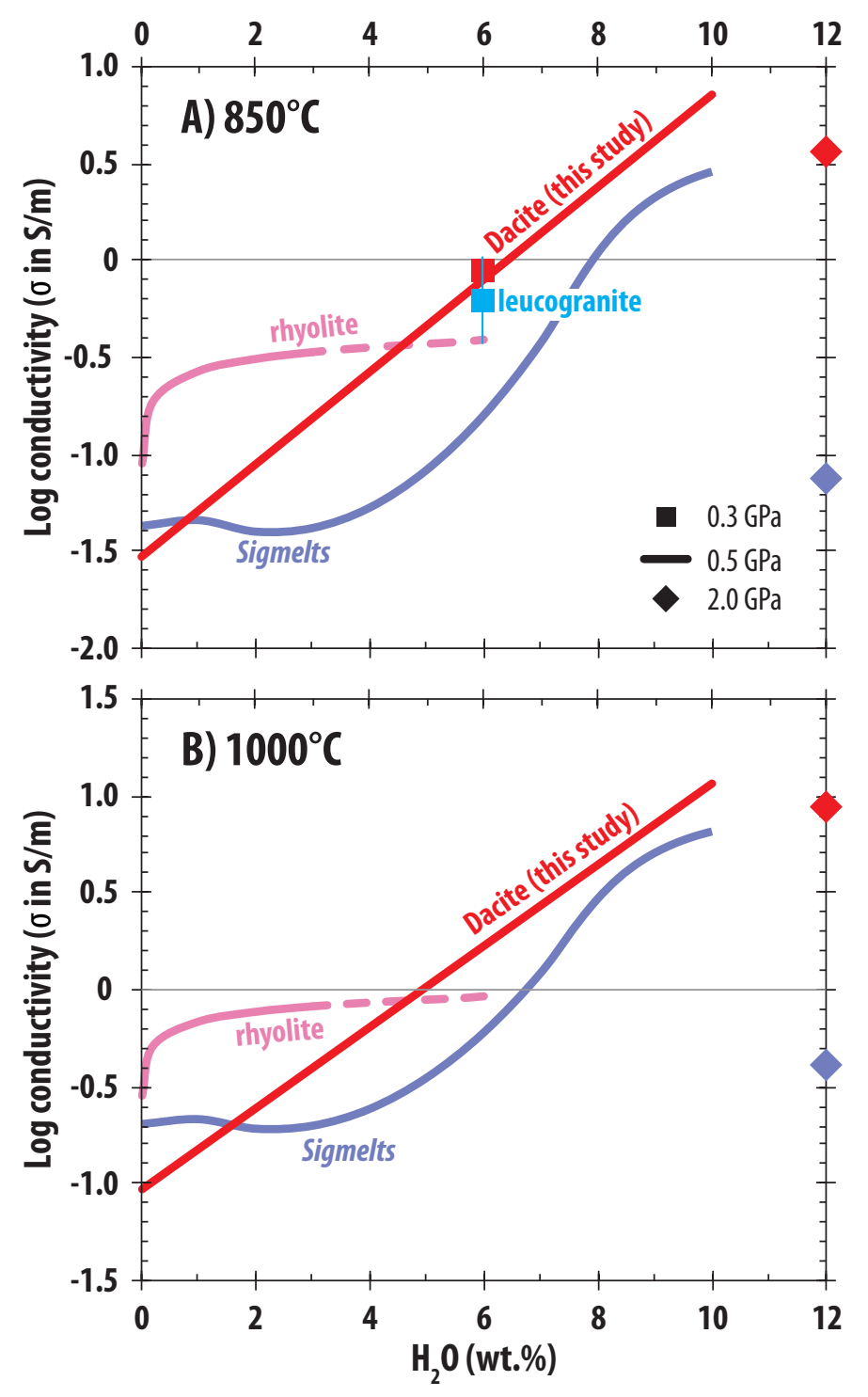

Laumonier et al., Fig. 9 

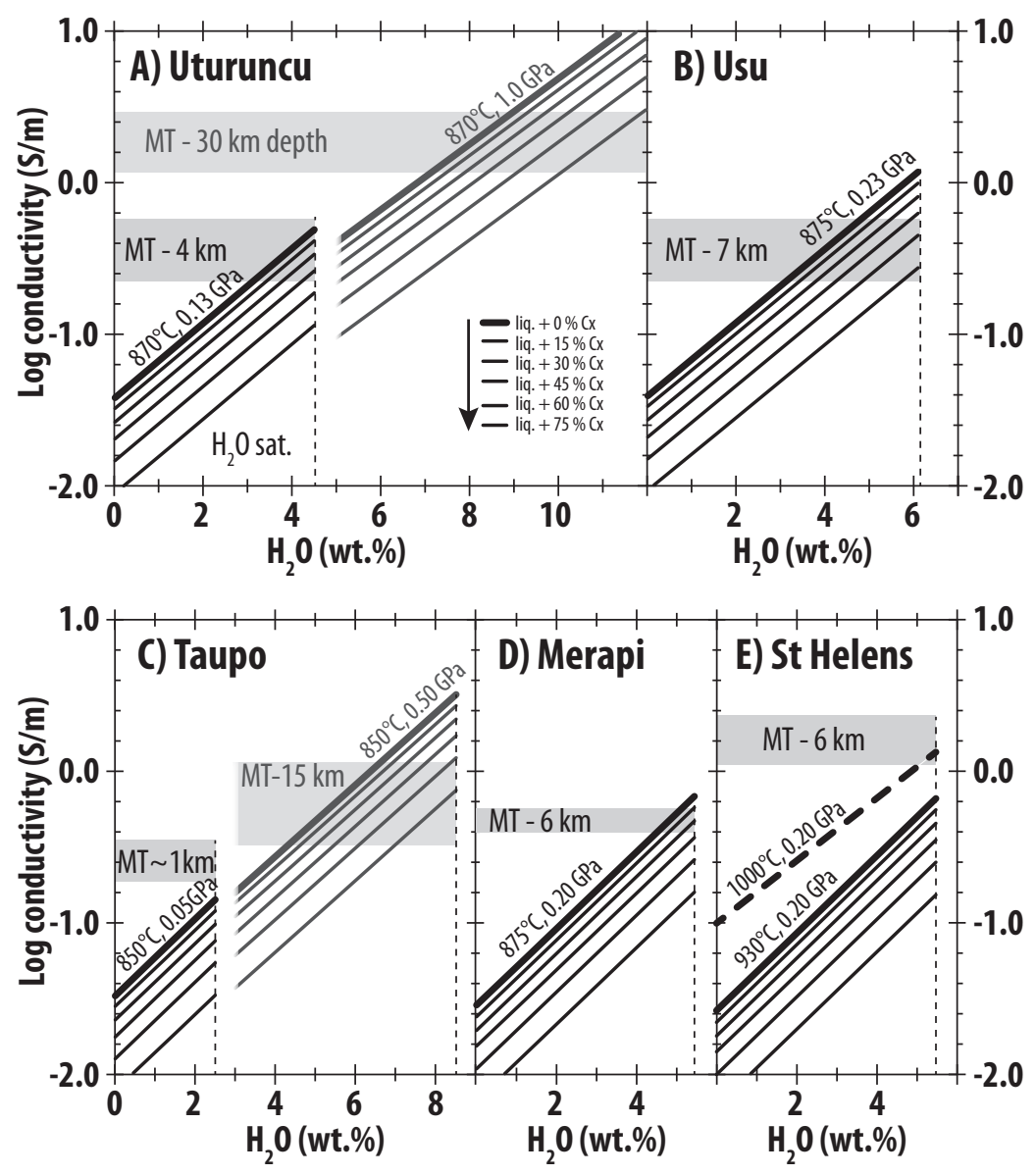

Laumonier et al., Fig. 10 


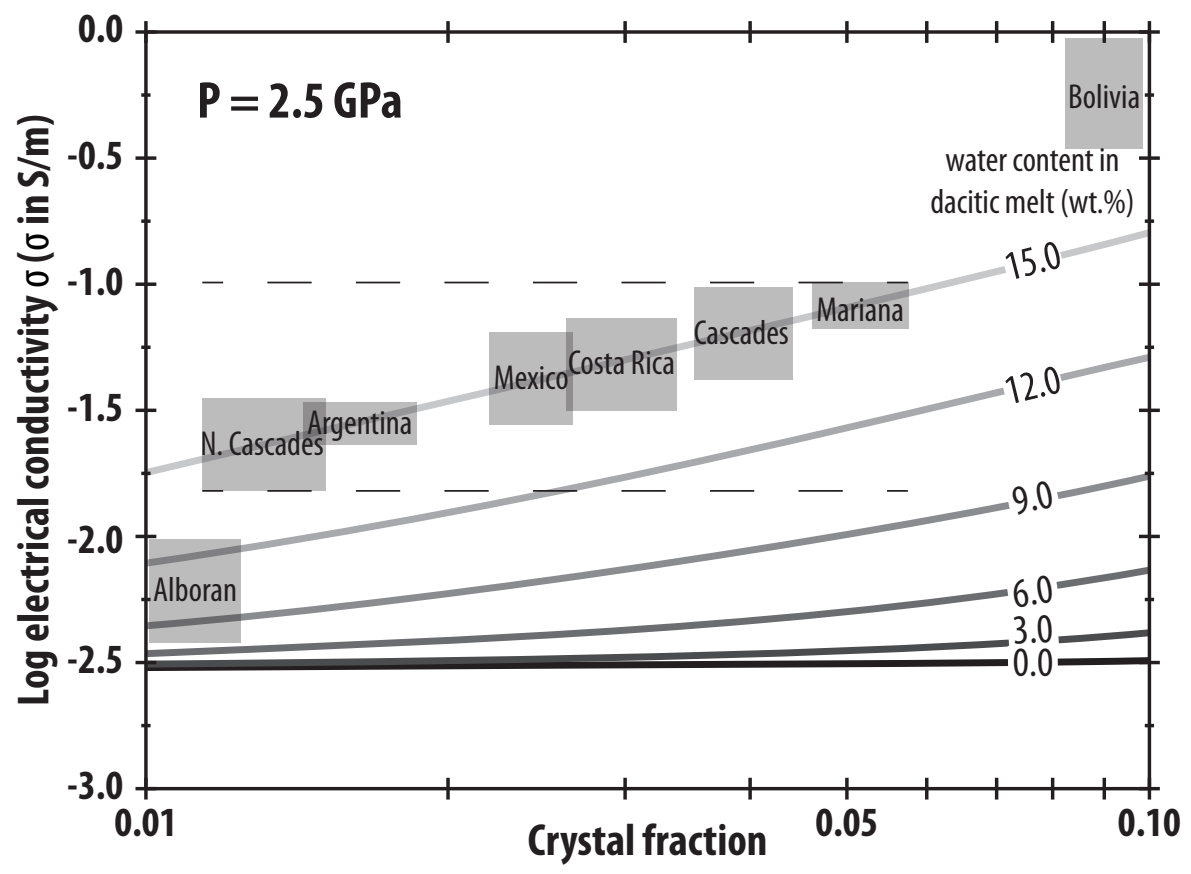

Laumonier et al., Fig. 11 

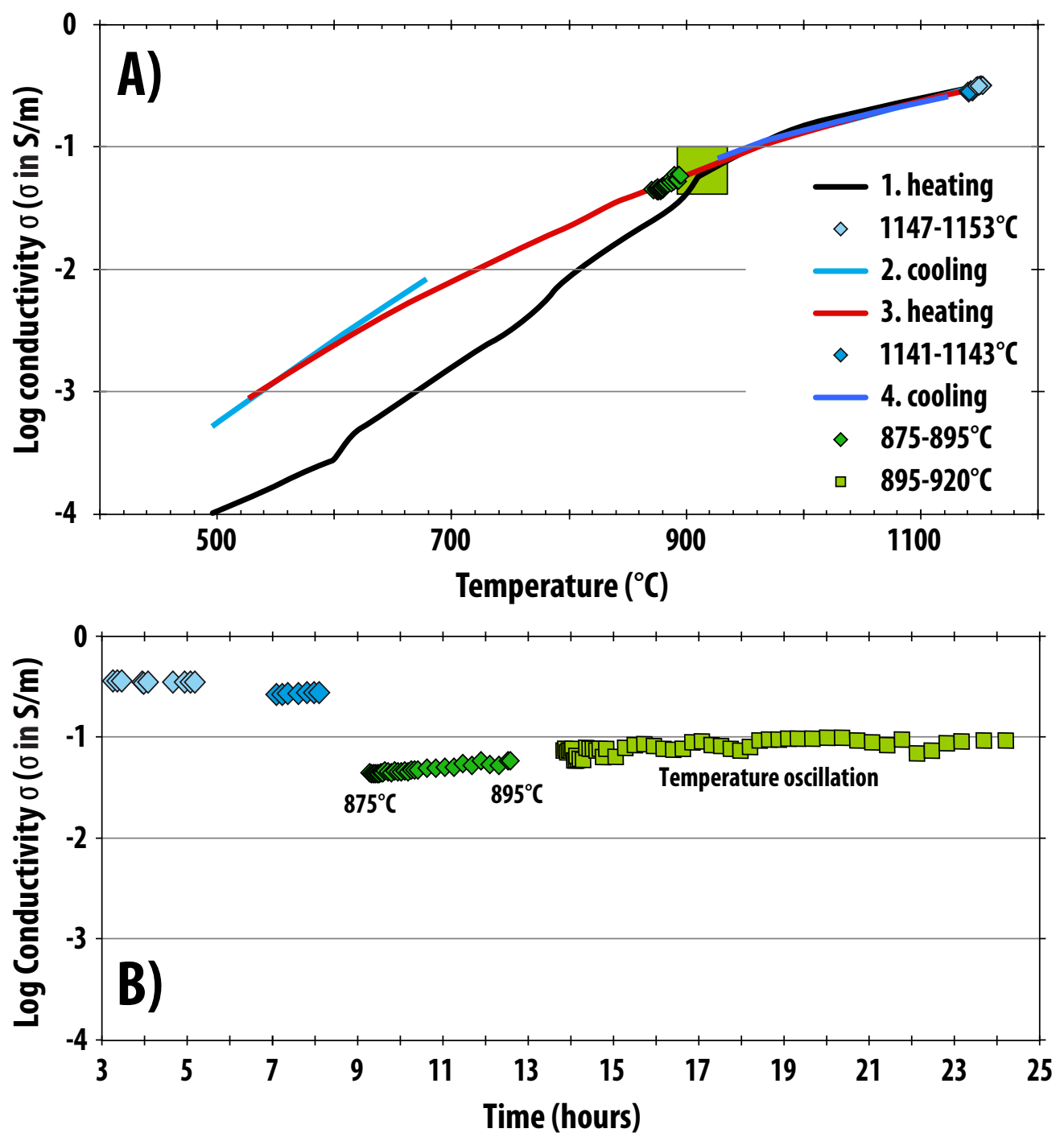

Laumonier et al., Fig. SI1 

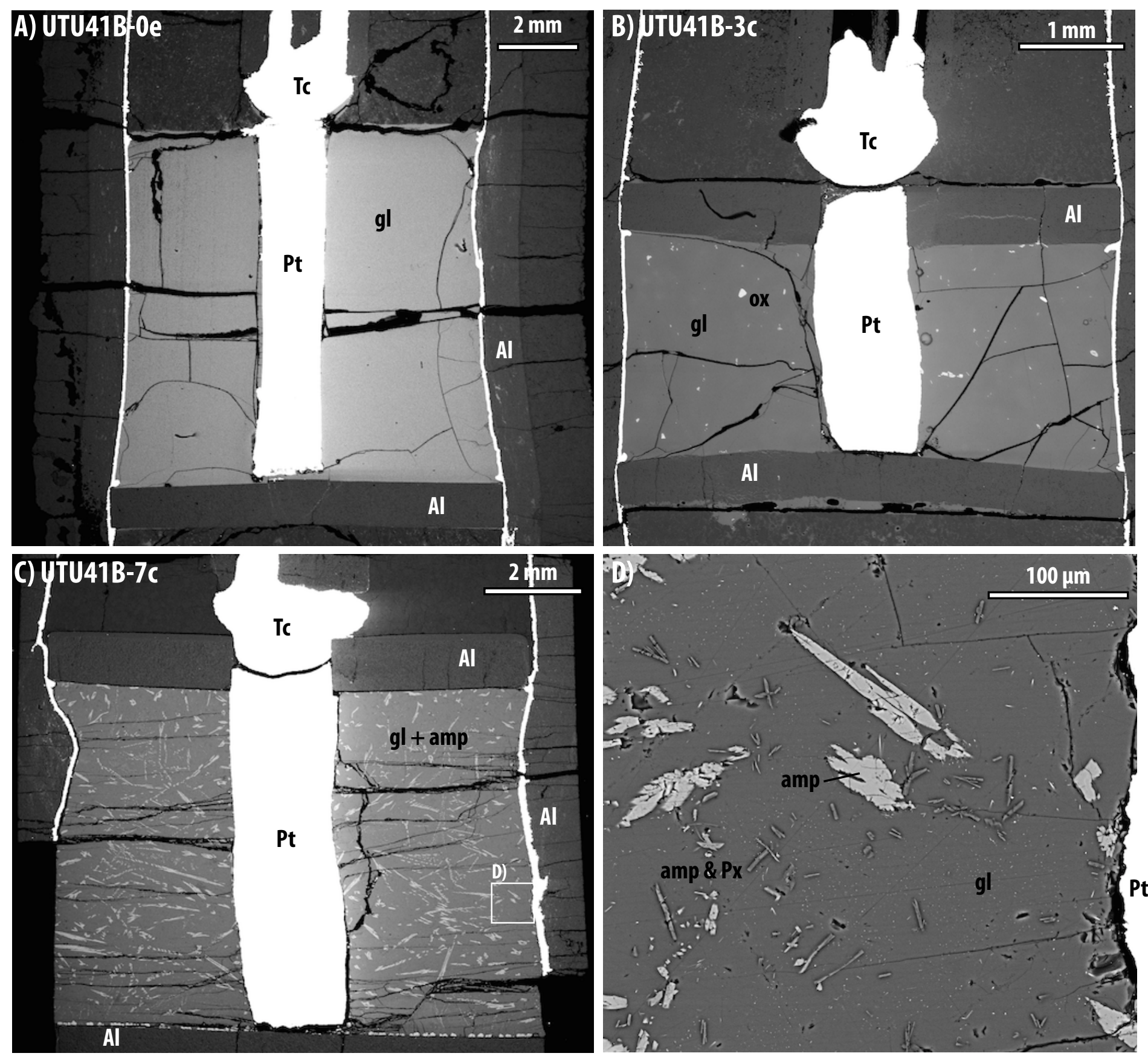

\section{Laumonier et al., Fig. SI2}




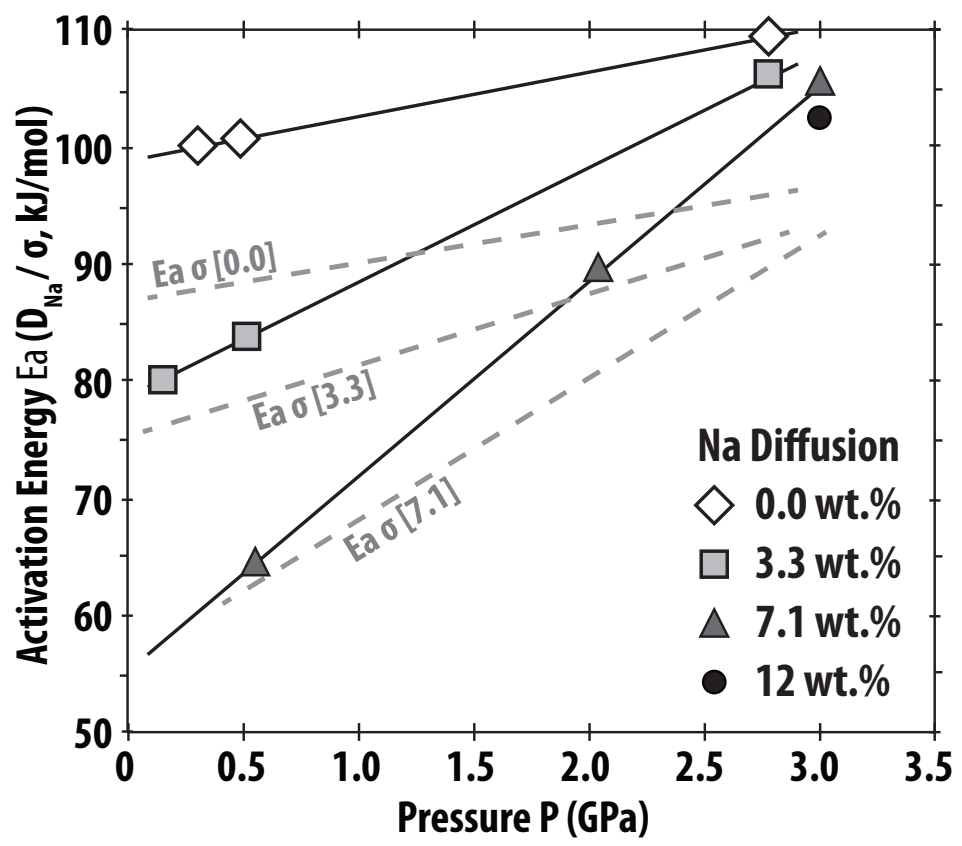

Laumonier et al., Fig. SI3 